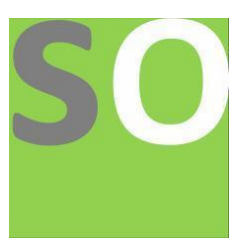

Article title: Hospital Response to COVID-19

A Consensus Report on Ain Shams University Hospital

Strategy

Authors: Eman Badawy Abdelfattah[1], samar Ahmed[2], Hany El-Zahapy[3], Amr El Said[4], Sameh Salem[5], Ayman Tharwat[6], Hesham Dabous[7], Hany Dabous[8], Yasser Mostafa[9], Ashraf Madkour[10], Hebatallah Said[11], Ossama Mansour[12], Shahira Samir[13], Samia Abdou[14], Ayman Saleh[15], Ashraf Omar[16], Abd El-Fattah Saoud[17], Mohamed Awad Tag El-Din[18], Mahmoud El-Meteini[19]

Affiliations: Ain Shams University[1]

Orcid ids: 0000-0001-8119-9258[2]

Contact e-mail: samar@med.asu.edu.eg

License information: This work has been published open access under Creative Commons Attribution License $\mathrm{http} / / / c r e a t i v e c o m m o n s . o r g / l i c e n s e s / b y / 4.0 /$, which permits unrestricted use, distribution, and reproduction in any medium, provided the original work is properly cited. Conditions, terms of use and publishing policy can be found at https://www.scienceopen.com/.

Preprint statement: This article is a preprint and has not been peer-reviewed, under consideration and submitted to ScienceOpen Preprints for open peer review.

DOI: 10.14293/S2199-1006.1.SOR-.PPD4QZX.v1

Preprint first posted online: 12 June 2020

Keywords: COVID, Emergency, Hospital SOP 


\section{Hospital Response to COVID-19}

\section{A Consensus Report on Ain Shams University Hospital Strategy}

\section{Context:}

Socioeconomically disadvantaged people are more frequent users of healthcare, ${ }^{1}$ as are the elderly. ${ }^{2}$ In particular, those in the most deprived decile access emergency services more than twice as often as the least deprived, ${ }^{3}$ and the Emergency Department is often used for routine care by marginalized groups who find it difficult to access General Practice and other community services. ${ }^{4}$ Therefore, disruption to elective or emergency care will have disproportionately large negative impacts on these marginalized groups.

In Ain Shams University Hospitals the situation is the same. The hospital serves a catchment area almost $50 \%$ of Cairo. This situation is now disrupted with the rapid onset COVID-19 pandemic and its effect on the health system.

Amidst a great deal of uncertainty and mixed messages from the WHO, Ministries of health and scientific communities, a methodology to keep the standard operating procedures of the school needs to be in place in order to allow the hospital to respond to its catchment area requirements.

Methods:

A number of focus groups were conducted with a targeted purposeful sample of service providers inside the Ain Shams University Hospitals. These were a total of 12 summit sessions guided by a set of questions:

What are the needs of the non COVID Patients?

What are the emergency needs of the COVID Patients?

What are the challenges that meet us in accommodating both?

What changes do we need to do to make the process smoother?

A total of 86 Focus group hours were exerted and attended by 72 active service providers from inside the university.

Data emerging from the focus groups was them stratified into themes and each of theme was later named as an "Objective". 
A planning team was assigned for each objective and 6 planning sessions were allocated for each team. Plans were done on a template plan and an algorithm.

A central team was assigned to refine the plans and integrate them into a central document (appendix 1)

\section{Results}

As a result of the focus groups four main themes/objectives arose:

\section{Decreasing hospital acquired infection and exposure}

The decisions made in the focus groups needed to be substantialized into an algorithm to show exact decisions and hospital locations needed to offer care in order to minimize hospital acquired infections. This included all triage work, clinics, in-patient and surgery wards. In order to make sure that service is offered in a clinically accepted fashion and that the hospital does not become a source of exacerbation of the community acquired infection. (Table 1)

\section{Managing patient flow}

The focus group participants agreed that as a first step definition of the case level is very important. Based on information from WHO and CDC it is important to also identify the cutoffs for our specific context. Table 1 show the consensus table for patient diagnosis level as identified in this study together with their treatment approaches.

Table (1): Consensus for diagnosis levels of confirmed COVID-19 cases

\section{Treatment of Confirmed Case of COVID-19}

\begin{tabular}{|l|c|c|c|c|}
\hline \multicolumn{5}{|c|}{ Asymptomatic } \\
\hline Presentation & $\begin{array}{c}\text { NO abnormal } \\
\text { lab findings or } \\
\text { HRCT findings of } \\
\text { COVID 19 } \\
\text { pneumonia }\end{array}$ & $\begin{array}{c}\text { Abnormal lab } \\
\text { findings or HRCT } \\
\text { findings of COVID } \\
19 \text { pneumonia }\end{array}$ & $\begin{array}{c}\text { No HRCT findings of } \\
\text { COVID 19 pneumonia } \\
\text { without risk factors }\end{array}$ & $\begin{array}{c}\text { No HRCT findings of COVID 19 } \\
\text { pneumonia with risk factors }\end{array}$ \\
\hline Site of care & $\begin{array}{c}\text { Home } \\
\text { isolation / } \\
\text { ASU Student } \\
\text { Dormitory }\end{array}$ & $\begin{array}{c}\text { Designated } \\
\text { Hospital } \\
\text { or Home } \\
\text { isolation/ ASU }\end{array}$ & $\begin{array}{c}\text { Home isolation } \\
\text { Or ASU Student } \\
\text { Dormitory }\end{array}$ & $\begin{array}{c}\text { Home isolation/ ASU Student } \\
\text { Dormitory or Designated } \\
\text { hospital * }\end{array}$ \\
\hline
\end{tabular}




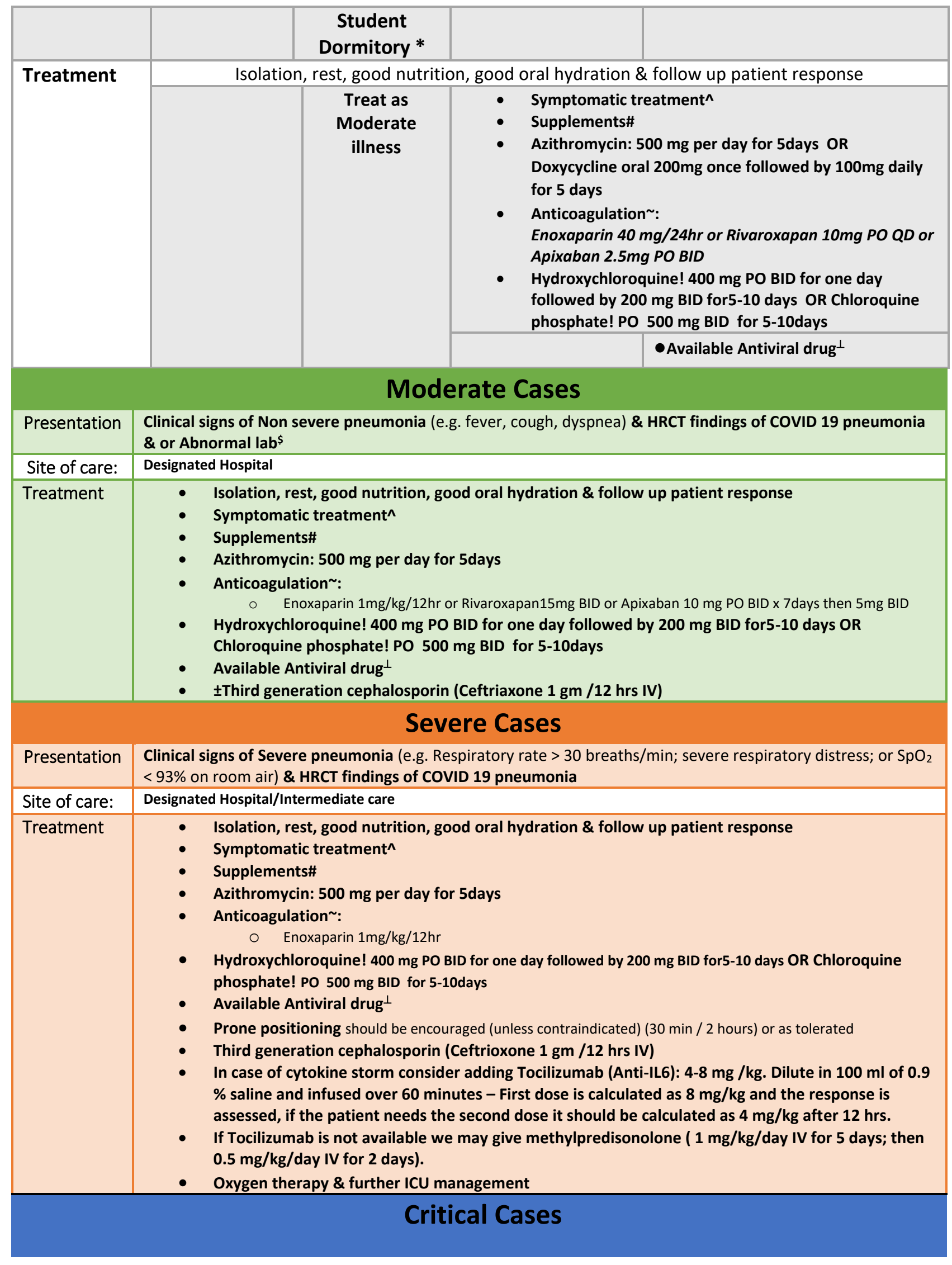




\begin{tabular}{|c|c|}
\hline Presentation & $\begin{array}{l}\text { Occurrence of respiratory failure requiring mechanical ventilation; Presence of shock; Sepsis, other organ failure } \\
\text { that requires monitoring and treatment in the ICU }\end{array}$ \\
\hline Site of care: & Designated Hospital/ ICU \\
\hline Treatment & 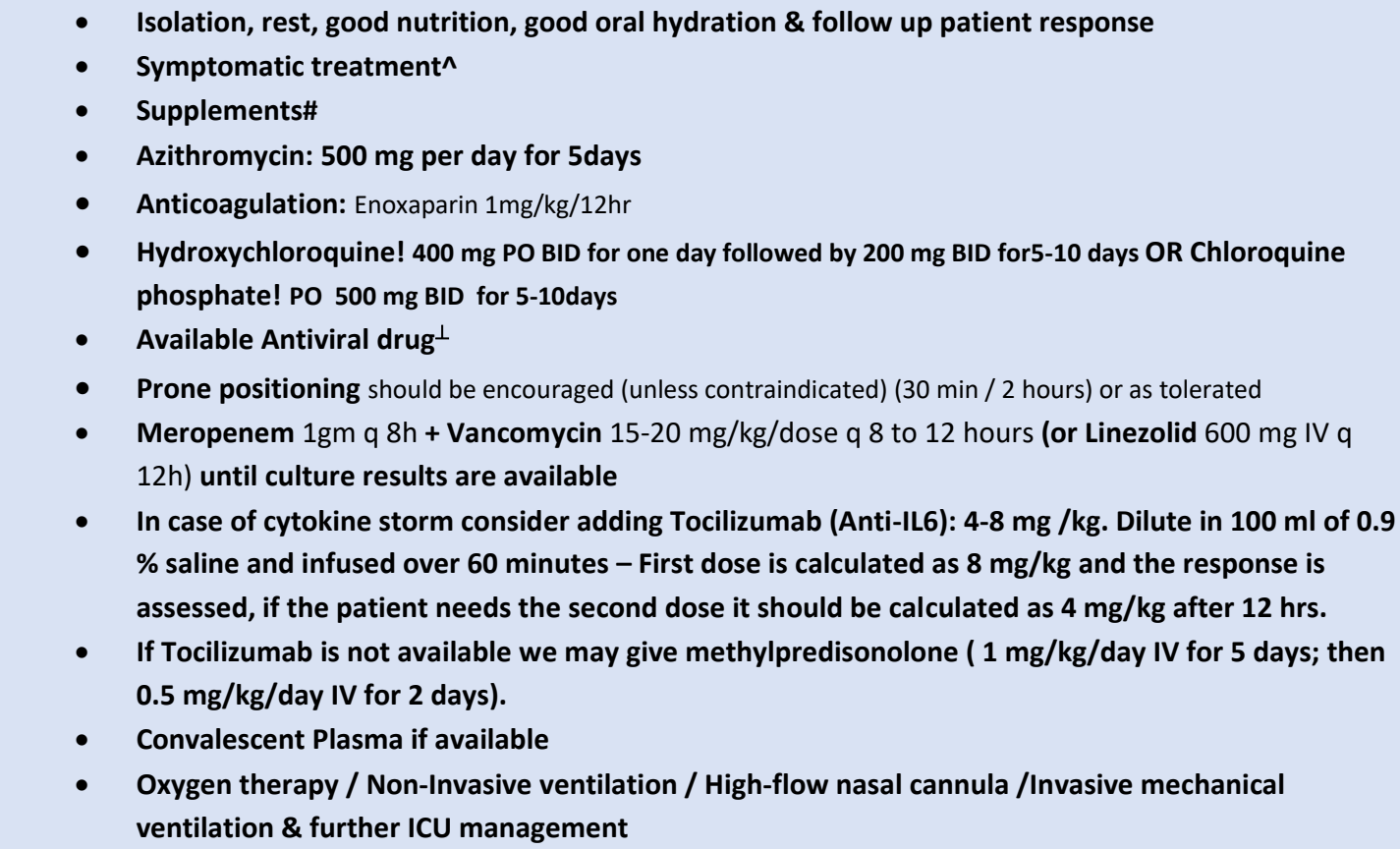 \\
\hline
\end{tabular}

\section{Managing patient progression in the treatment trip}

The focus group attendees identified a number of required tests and testing plans and allocated the cut off decisions needed to be made. Criteria for diagnosis ultimately fed into the decisions of site of care. Table 2 shows the consensus routine testing plan approved by the focus group attendees

Table 2: Consensus table on investigations for patient progression 


\begin{tabular}{|c|c|c|c|}
\hline Severity & Laboratory & Radiology & ECG \\
\hline Mild cases & $\begin{array}{l}\mathrm{CBC}, \mathrm{CRP}, \mathrm{D} \text {-dimer, Ferritin, Liver } \\
\text { function tests (ALT - AST) and } \\
\text { kidney function tests (S.cr- BUN). } \\
\text { Base line, not required to be } \\
\text { repeated unless there is } \\
\text { symptomatic progression } \\
\text { In case of comorbidity: follow up } \\
\text { necessary lab as needed }\end{array}$ & $\begin{array}{l}\text { HRCT of the chest } \\
\text { Only repeat if } \\
\text { there is } \\
\text { symptomatic } \\
\text { progression }\end{array}$ & $\begin{array}{l}\text { Baseline ECG ( QTC is } \\
\text { considered prolonged if } \\
\text { greater than } 450 \mathrm{~ms} \text { in } \\
\text { males and } 470 \mathrm{~ms} \text { in } \\
\text { females). } \\
\text { Only if the patient will } \\
\text { receive azithromycin } \\
\text { and/or } \\
\text { hydroxychloroquine }\end{array}$ \\
\hline $\begin{array}{l}\text { Moderate } \\
\text { cases }\end{array}$ & $\begin{array}{l}\text {-CBC, CRP, D-dimer, Ferritin, } \\
\text { Liver function tests (ALT - AST) } \\
\text { and kidney function tests (S.cr- } \\
\text { BUN). } \\
\text { - Base line. } \\
\text { - Only abnormal findings are } \\
\text { required to be repeated as } \\
\text { needed } \\
\text { In case of comorbidity: follow up } \\
\text { necessary lab as needed }\end{array}$ & $\begin{array}{l}\text { Repeat if there is } \\
\text { symptomatic } \\
\text { progression and } \\
\text { after } 2 \text { weeks of } \\
\text { discharge }\end{array}$ & $\begin{array}{l}\text { Baseline ECG ( QTc is } \\
\text { considered prolonged if } \\
\text { greater than } 450 \mathrm{~ms} \text { in } \\
\text { males and } 470 \mathrm{~ms} \text { in } \\
\text { females). } \\
\text { Repeat every other day in } \\
\text { patients receiving } \\
\text { azithromycin and/ or } \\
\text { hydroxychloroquine }\end{array}$ \\
\hline Severe cases & $\begin{array}{l}\text {-CBC, CRP, D-dimer, Ferritin, } \\
\text { Liver function tests (ALT - AST) } \\
\text { and kidney function tests (S.cr- } \\
\text { BUN). } \\
\text { - Base line. } \\
\text { - Only abnormal findings are } \\
\text { required to be repeated as } \\
\text { needed } \\
\text { In case of comorbidity: follow up } \\
\text { necessary lab as needed }\end{array}$ & $\begin{array}{l}\text { Repeat if there is } \\
\text { symptomatic } \\
\text { progression and } \\
\text { after } 2 \text { weeks of } \\
\text { discharge }\end{array}$ & $\begin{array}{l}\text { Baseline ECG ( QTC is } \\
\text { considered prolonged if } \\
\text { greater than } 450 \mathrm{~ms} \text { in } \\
\text { males and } 470 \mathrm{~ms} \text { in } \\
\text { females). } \\
\text { Repeat every other day in } \\
\text { patients receiving } \\
\text { azithromycin and } \\
\text { hydroxychloroquine }\end{array}$ \\
\hline Critical cases & $\begin{array}{l}\text { - CBC with differential, } \\
\text { Urea/Electrolytes, Creatinine, } \\
\text { CRP, LFTs, Ferritin, D-dimer, } \\
\text { procalcitonin, Triglycerides, }\end{array}$ & HRCT chest & $\begin{array}{l}\text { Baseline ECG ( QTC is } \\
\text { considered prolonged if } \\
\text { greater than } 450 \mathrm{~ms} \text { in }\end{array}$ \\
\hline
\end{tabular}




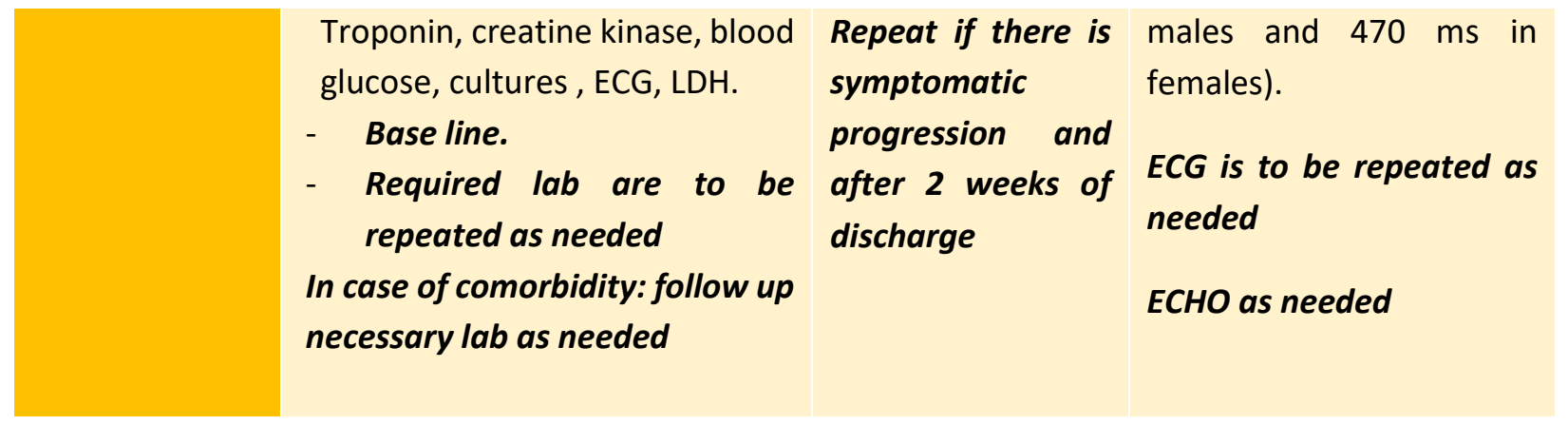

\section{Decisions on patient discharge}

The decision on patient discharge is one of the most important determinants of the quality of health service. It is important for physicians to feel empowered to make discharge decisions knowing that the patient care is not jeopardized and that the community at large is not at risk based on these decisions. The most important outcome of this work materialized from the task force that was responsible for this objective and a decision was made to make sure that there exited a hospital workflow document COVID and on house quarantine. (Appendix 2, 3)

\section{Concluding statement}

Every hospital needs to make sure that its SOPs are set in place during this tough time and it is mandatory to engage stakeholders in the process and in the outcome assessment. This work is still work in progress and by submitting it to preprint we are hoping to gain more consensus and open a scientific discussion regarding

\section{References}

Cookson, R, Propper, C, Asaria, M, et al. Socio-Economic Inequalities in Health Care in England. Fisc Stud 2016; 37: 371-403.

Google Scholar | Crossref

Propper, C, Stoye, G, Zaranko, B. The wider impacts of the coronavirus pandemic on the NHS, London: Institute for Fiscal Studies, 2020.

Google Scholar

NHS Digital. Hospital Accident and Emergency Activity 2018 19. See https://digital.nhs.uk/data-andinformation/publications/statistical/hospital-accident--emergency-activity/2018-19\# (2019, last 
checked 26 April 2020).

Google Scholar

MacKichan, F, Brangan, E, Wye, L, et al. Why do patients seek primary medical care in emergency

departments? An ethnographic exploration of access to general practice. BMJ Open 2017;

7: e013816-e013816.

Google Scholar | Crossref | Medline

Home care for patients with COVID-19 presenting with mild symptoms and management of their contacts- Interim guidance

https://apps.who.int/iris/rest/bitstreams/1272288/retrieve

Interim Guidance for Implementing Home Care of People Not Requiring Hospitalization for Coronavirus Disease 2019 (COVID-19)

https://www.cdc.gov/coronavirus/2019-ncov/downloads/guidance-home-care.pdf

Ain Shams University Designated hospitals Consensus Statement on Management of Adult COVID-19 patients (May 2020)

منشور ات توعوية وزارة الصحة و السكان المصري

http://www.mohp.gov.eg/

Appendix 1

Consensus Statement 


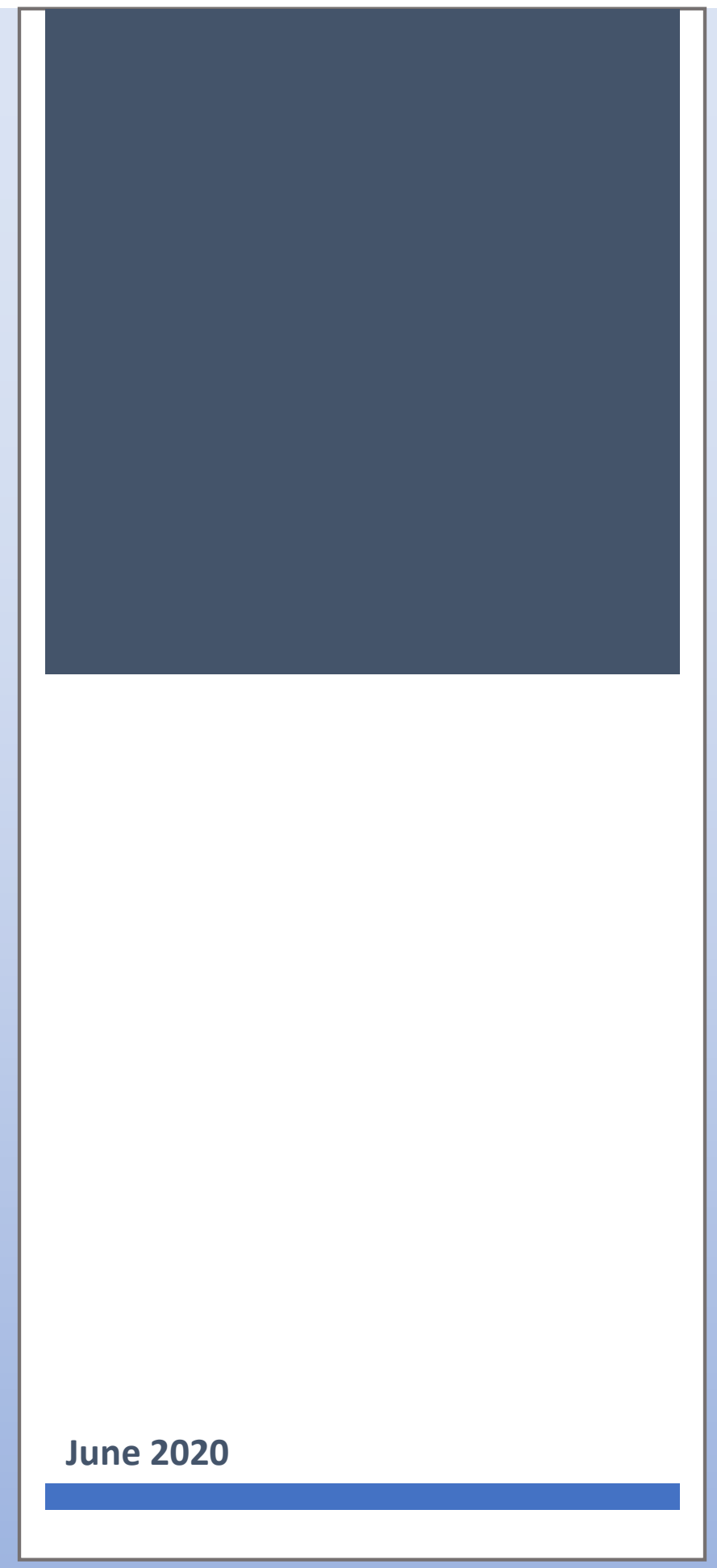




\section{Ain Shams University Hospitals Consensus Statement on Management of Adult COVID-19 Patients}

This is an updatable dynamic statement based on current available information and clinical experience.

\section{Objectives:}

Based on the best available scientific evidence and expert opinion, the objective of this document is to provide guidance on clinical management of the COVID-19 infection in Ain Shams university hospitals 
Ain Shams University Hospitals COVID-19 Suspected Cases Algorithm

\section{Suspected case}

Health care workers \& Ain Shams University staff

\section{Triage Clinic for Evaluation\$}

Assess clinical /laboratory /HRCT/ Take PCR sample

\section{Suspected case}

In patient

Assess by Chest department Assess clinical /laboratory /HRCT/ Take PCR sample

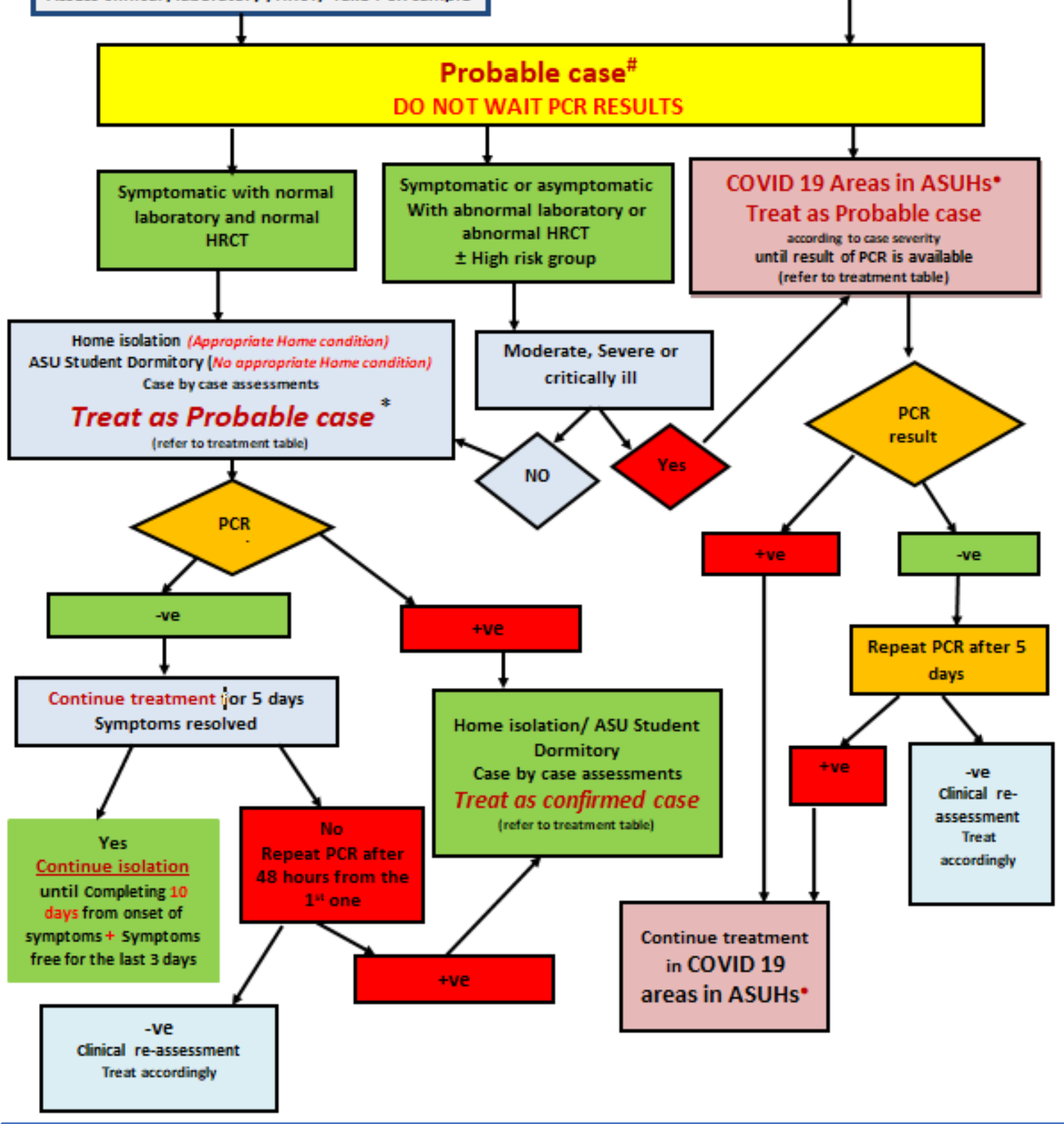

\$From 8 am to $8 \mathrm{pm}$ covered by Family Medicine / From $8 \mathrm{pm}$ to $8 \mathrm{am}$ covered by Internal Medicine in ER $\rightarrow$ Responsible to evaluate case and confirm the transfer of the case to site of care

IF THE PATIENT'S CONDITION DETERRIOATES at any time during treatment admit in COVID 19 area*

\# Clinical and radiological picture compatible with CVOID19 infection awaiting PCR result or repeatedly Negative PCR tests collected from different sites with no microbiological evidence of another Infectious etiology

-COVID 19 Areas in ASUHs: Obour hospital, Geriatric hospital, Field hospital and other areas (ER-ICU, old ER, Female Ophthalmology 


\section{Treatment Summary}

\section{Treatment of Confirmed Case of COVID-19}

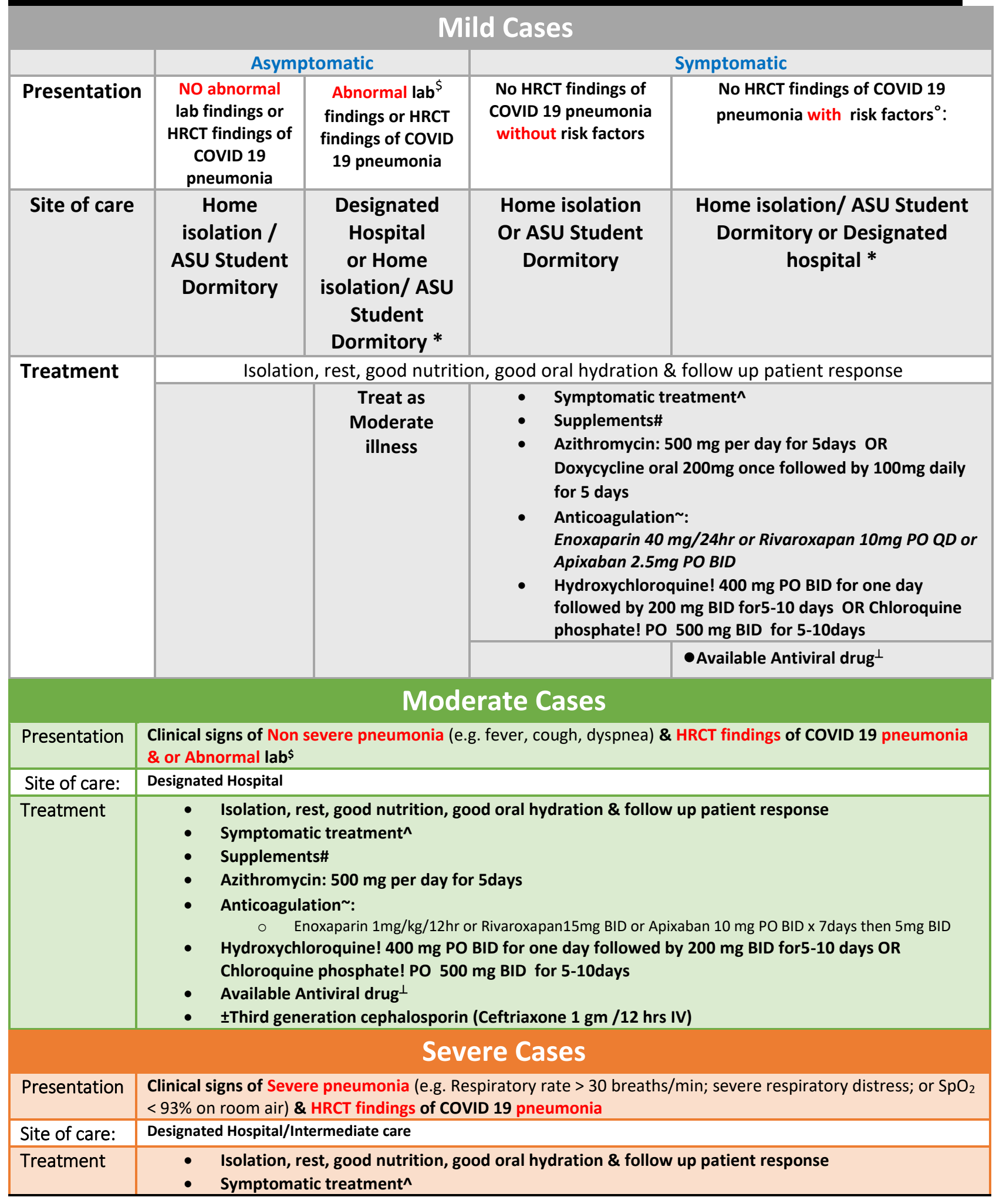




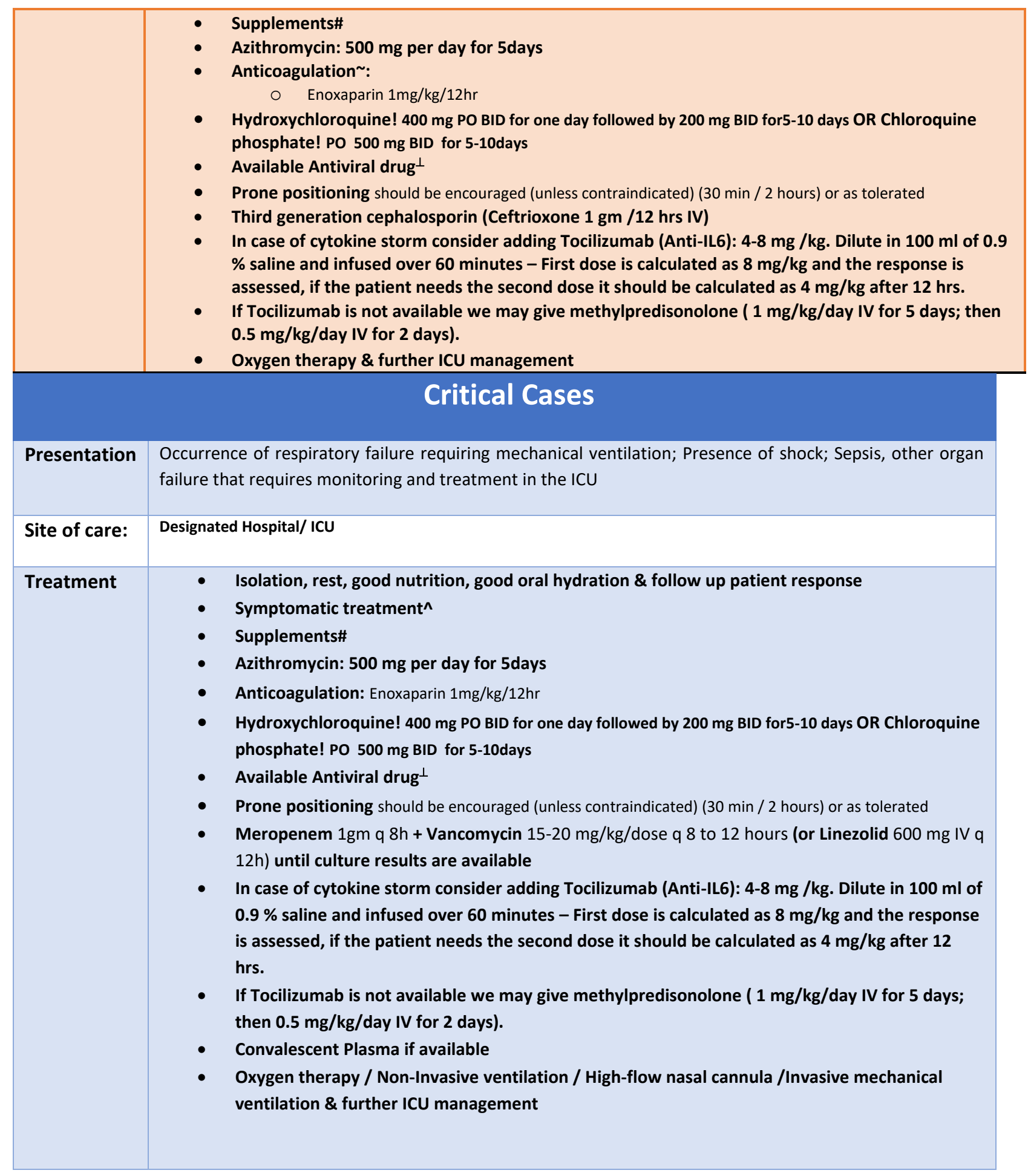




\section{Remarks:}

- ASU: Ain Shams University Student Dormitory

- *Case by case assessment

- $\quad \$$ Treat at home if D-dimer $<1 \mathrm{mg} / \mathrm{L}$, Absolute lymphopenia $<800 / \mu \mathrm{l}$, Ferritin $<500 \mathrm{ng} / \mathrm{ml}$., liver function within normal otherwise treat at Designated hospital

- ': High-risk group: Age above 60 years old, Obesity (BMl>40), pregnancy, comorbidities e.g. cardiovascular disease, diabetes, hypertension, chronic kidney disease or chronic respiratory disease (Asthma, COPD)...etc, Immunosuppressive diseases or drugs or active Malignancy

- If D-dimer $\geq \mathbf{1 ~ m g / L ~ c o n s i d e r ~ t h e r a p e u t i c ~ a n t i c o a g u l a t i o n ~}$

- ! Baseline ECG \& follow up whenever needed (Contraindicated when QTC > than $450 \mathrm{~ms}$ in males and 470 ms in females, Myasthenia gravis, Retinal damage, Epilepsy, G6PD deficiency, Chronic Heart, Kidney or Liver disease \& Arrythmias. Maximum duration 5 days in all types of disease categories in outside hospital setting or where close cardiac ECG monitoring cannot be possible.

- $\quad \perp$ Antiviral drug: e.g. Lopinavir-Ritonavir (200/50mg) 2 tablets bid for 5-10 days. Oseltamivir is a neuraminidase inhibitor an enzyme not found on coronaviruses. Therefore, no activity is expected.

- If patient's condition deteriorates, upgrade level of care, with immediate arrangement for transfer to hospital

- NSymptomatic treatment

- Fever and myalgia: Paracetamol $500 \mathrm{mg}$ PRN or up to $2 \mathrm{gm} /$ day-

- GIT symptoms: Motility regulator (e.g. Mosapride 2.5.mg 1x3 half an hour before meals) + PPI (Omeperazole $40 \mathrm{mg} 1 \times 1$ half an hour before breakfast).

- \#Supplements:

- Vitamin C 1 gm/ day.

- $\quad$ Zinc 50 mg per day.

\begin{tabular}{|l|l|}
\hline \multicolumn{2}{|c|}{ Treatment of Probable Case of COVID 19+ Symptoms } \\
\hline Presentation & $\begin{array}{l}\text { Clinical and radiological picture compatible with CVOID19 infection awaiting PCR result or repeatedly } \\
\text { Negative PCR tests collected from different sites with no microbiological evidence of another Infectious } \\
\text { etiology }\end{array}$ \\
\hline Site of care: & Home isolation or hospital * \\
\hline Treatment & $\begin{array}{l}\text { Managed as the confirmed cases in time of pandemic until PCR result is available } \\
\text { Case management should follow COVID } 19 \text { severity stratification (mild, } \\
\text { moderate, severe, or critical) }\end{array}$ \\
\hline
\end{tabular}


Table1: RT-PCR timeline:

\begin{tabular}{|l|l|}
\hline Home isolation or Student dormitory isolation & $\begin{array}{l}\text { RT-PCR is required at the end of the isolation } \\
\text { period if not available Continue isolation until } \\
\text { Completing } 10 \text { days from onset of symptoms + } \\
\text { Symptoms free for the last } 3 \text { days without } \\
\text { medication }\end{array}$ \\
\hline Designated hospital isolation & $\begin{array}{l}\text { NB: Cough and anosmia may be the only } \\
\text { persistent symptoms left }\end{array}$ \\
\hline $\begin{array}{l}\text { RT-PCR is required after } 5 \text { days of treatment } \\
\text { If negative repeat after } 24 \text { hrs if still } \\
\text { negative; stop treatment and continue } \\
\text { isolation for } 10 \text { days. } \\
\text { If positive repeat every } 48 \text { hrs. }\end{array}$ \\
\hline
\end{tabular}

Table 2: Investigations schedule:

\begin{tabular}{|c|c|c|c|}
\hline Severity & Laboratory & Radiology & ECG \\
\hline Mild cases & $\begin{array}{l}\text { CBC, CRP, D-dimer, Ferritin, Liver } \\
\text { function tests (ALT - AST) and } \\
\text { kidney function tests (S.cr- BUN). } \\
\text { Base line, not required to be } \\
\text { repeated unless there is } \\
\text { symptomatic progression } \\
\text { In case of comorbidity: follow up } \\
\text { necessary lab as needed }\end{array}$ & $\begin{array}{l}\text { HRCT of the chest } \\
\text { Only repeat if } \\
\text { there is } \\
\text { symptomatic } \\
\text { progression }\end{array}$ & $\begin{array}{l}\text { Baseline ECG ( QTc is } \\
\text { considered prolonged if } \\
\text { greater than } 450 \mathrm{~ms} \text { in } \\
\text { males and } 470 \mathrm{~ms} \text { in } \\
\text { females). } \\
\text { Only if the patient will } \\
\text { receive azithromycin } \\
\text { and/or } \\
\text { hydroxychloroquine }\end{array}$ \\
\hline $\begin{array}{l}\text { Moderate } \\
\text { cases }\end{array}$ & $\begin{array}{l}\text {-CBC, CRP, D-dimer, Ferritin, } \\
\text { Liver function tests (ALT - AST) } \\
\text { and kidney function tests (S.cr- } \\
\text { BUN). } \\
\text { - Base line. } \\
\text { - Only abnormal findings are } \\
\text { required to be repeated as } \\
\text { needed }\end{array}$ & $\begin{array}{l}\text { Repeat if there is } \\
\text { symptomatic } \\
\text { progression and }\end{array}$ & $\begin{array}{l}\text { Baseline ECG ( QTc is } \\
\text { considered prolonged if } \\
\text { greater than } 450 \mathrm{~ms} \text { in } \\
\text { males and } 470 \mathrm{~ms} \text { in } \\
\text { females). } \\
\text { Repeat every other day in } \\
\text { patients receiving }\end{array}$ \\
\hline
\end{tabular}




\begin{tabular}{|c|c|c|c|}
\hline & $\begin{array}{l}\text { In case of comorbidity: follow up } \\
\text { necessary lab as needed }\end{array}$ & $\begin{array}{l}\text { after } 2 \text { weeks of } \\
\text { discharge }\end{array}$ & $\begin{array}{l}\text { azithromycin and/ or } \\
\text { hydroxychloroquine }\end{array}$ \\
\hline Severe cases & $\begin{array}{l}\text {-CBC, CRP, D-dimer, Ferritin, } \\
\text { Liver function tests (ALT - AST) } \\
\text { and kidney function tests (S.cr- } \\
\text { BUN). } \\
\text { - Base line. } \\
\text { - Only abnormal findings are } \\
\text { required to be repeated as } \\
\text { needed } \\
\text { In case of comorbidity: follow up } \\
\text { necessary lab as needed }\end{array}$ & $\begin{array}{l}\text { Repeat if there is } \\
\text { symptomatic } \\
\text { progression and } \\
\text { after } 2 \text { weeks of } \\
\text { discharge }\end{array}$ & $\begin{array}{l}\text { Baseline ECG ( QTc is } \\
\text { considered prolonged if } \\
\text { greater than } 450 \mathrm{~ms} \text { in } \\
\text { males and } 470 \mathrm{~ms} \text { in } \\
\text { females). } \\
\text { Repeat every other day in } \\
\text { patients receiving } \\
\text { azithromycin and } \\
\text { hydroxychloroquine }\end{array}$ \\
\hline Critical cases & $\begin{array}{l}\text { - CBC with differential, } \\
\text { Urea/Electrolytes, Creatinine, } \\
\text { CRP, LFTs, Ferritin, D-dimer, } \\
\text { procalcitonin, Triglycerides, } \\
\text { Troponin, creatine kinase, blood } \\
\text { glucose, cultures, ECG, LDH. } \\
\text { - Base line. } \\
\text { - Required lab are to be } \\
\text { repeated as needed } \\
\text { In case of comorbidity: follow up } \\
\text { necessary lab as needed }\end{array}$ & $\begin{array}{l}\text { Repeat if there is } \\
\text { symptomatic } \\
\text { progression and } \\
\text { after } 2 \text { weeks of } \\
\text { discharge }\end{array}$ & $\begin{array}{l}\text { Baseline ECG ( QTc is } \\
\text { considered prolonged if } \\
\text { greater than } 450 \mathrm{~ms} \text { in } \\
\text { males and } 470 \mathrm{~ms} \text { in } \\
\text { females). } \\
\text { ECG is to be repeated as } \\
\text { needed } \\
\text { ECHO as needed }\end{array}$ \\
\hline
\end{tabular}

This is an updatable dynamic statement based on current available information and clinical experience 


\section{Case Definition:}

\section{- Suspect case}

A. A patient with any acute respiratory illness (fever and at least one sign/symptom of respiratory disease, e.g., cough, shortness of breath) AND having been in contact with a confirmed or probable COVID-19 case (see definition of contact page 27) in the last 10 days prior to symptom onset;

OR

B. A patient with acute respiratory illness (fever and at least one sign/symptom of respiratory disease, e.g., cough, shortness of breath), AND a history of travel to or residence in a location reporting community transmission of COVID-19 disease during the 10 days prior to symptom onset;

OR

C. A patient with severe acute respiratory illness (fever and at least one sign/symptom of respiratory disease, e.g., cough, shortness of breath; AND requiring Designated hospitalization) AND in the absence of an alternative diagnosis that fully explains the clinical presentation.

OR

D.A patient with non-specific symptoms, such as Fever, new loss of taste or smell, rigors, muscle pains, sore throat, nasal congestion, headache, diarrhea, nausea, vomiting and in the absence of an alternative diagnosis that fully explains the clinical presentation.

- Probable case

A patient with clinical and radiological picture compatible with CVOID19 infection awaiting PCR result or repeatedly Negative PCR tests collected from different sites with no microbiological evidence of another Infectious etiology

\section{- Confirmed case}

A patient with laboratory confirmation (Positive RT-PCR) of COVID-19 infection, irrespective of clinical signs and symptoms.

\section{Clinical Findings and Complications}

Some patients with initially mild symptoms may progress over the course 5-7 days from symptom onset. Also, patients may present as asymptomatic contacts to confirmed case of COVID-19)

Clinical Symptoms: Signs and symptoms include:

- Fever

- Cough

- Myalgia or fatigue 
- Shortness of breath

- Sore throat

- Runny nose

- Diarrhea and nausea

- Muscle ache

- Headache

- Pneumonia and ARDS

- Loss of sense of smell and/ or taste.

- Renal failure, pericarditis and Disseminated Intravascular Coagulation

\section{Complications:}

- Severe Pneumonia

- Acute Respiratory Failure and ARDS

- Acute Renal failure

- Disseminated intravascular coagulation

- Sepsis or septic shock

High-risk group

- Age above 60 years old

- Obesity (BMI>40)

- Pregnancy

- Comorbidities e.g. Cardiovascular disease, Diabetes, Hypertension, chronic kidney disease or Chronic Respiratory disease (Asthma, COPD)...etc

- Immunosuppressive diseases or drugs

- Active Malignancy 


\begin{tabular}{|c|c|c|}
\hline \multicolumn{3}{|c|}{ Table 3: COVID-19 disease severity } \\
\hline Mild disease & & $\begin{array}{l}\text { Symptomatic patients meeting the case definition for COVID-19 without } \\
\text { radiological evidence of pneumonia or hypoxia }\end{array}$ \\
\hline $\begin{array}{l}\text { Moderate } \\
\text { disease }\end{array}$ & Pneumonia & $\begin{array}{l}\text { Adult with clinical signs of non severe pneumonia (e.g. fever, cough, dyspnea) and } \\
\text { radiological evidence of pneumonia }\end{array}$ \\
\hline Severe disease & $\begin{array}{l}\text { Severe } \\
\text { pneumonia }\end{array}$ & 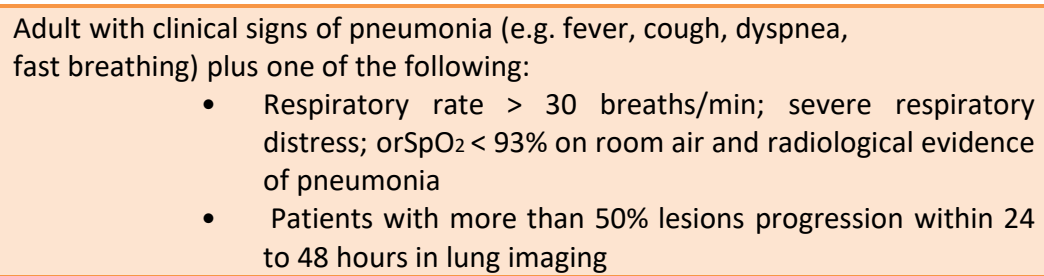 \\
\hline $\begin{array}{l}\text { Critical } \\
\text { disease }\end{array}$ & $\begin{array}{l}\text { Acute } \\
\text { respiratory } \\
\text { distress } \\
\text { syndrome } \\
\text { (ARDS) }\end{array}$ & $\begin{array}{l}\text { Meeting any of the following criteria: } \\
\text { Occurrence of respiratory failure requiring mechanical ventilation; Presence of } \\
\text { shock; Sepsis, other organ failure that requires monitoring and treatment in the } \\
\text { ICU } \\
\text { Critical cases are further divided according to the degree of hypoxemia as } \\
\text { categorized by the P/F ratio (PaO2/FiO2 } * 100 \text { ) or S/F ratio - } \\
\text { - Early stage: PO2/FiO2 (P/F ratio) } 200-300 \text {, or Oxygen saturation by pulse } \\
\text { oximetry/ Fraction of inspired oxygen (S/F ratio) } 181-235 \text {; without organ failure } \\
\text { other than the lungs. The patient has a great chance of recovery through active } \\
\text { antiviral, anti-cytokine storm, and supportive treatment. } \\
\text { - Middle stage: P/F ratio } 100-200 \text {, or S/F ratio } 118-181 \text {; may be complicated by } \\
\text { other mild or moderate dysfunction of other organs. } \\
\text { - Late stage: P/F ratio less than } 100, S \backslash F \text { ratio less than } 118 \text {; diffuse consolidation } \\
\text { of both lungs; or failure of other vital organs. The mortality risk is significantly } \\
\text { increased. } \\
\text { Sepsis: acute life-threatening organ dysfunction caused by a dysregulated host } \\
\text { response to suspected or proven infection. Signs of organ dysfunction include: } \\
\text { altered mental status, difficult or fast breathing, low oxygen saturation, reduced } \\
\text { urine output, fast heart rate, weak pulse, cold extremities or low blood pressure, } \\
\text { skin mottling, laboratory evidence of coagulopathy, thrombocytopenia, acidosis, } \\
\text { high lactate, or hyperbilirubinemia. } \\
\text { Septic shock: persistent hypotension despite volume resuscitation, requiring } \\
\text { vasopressors to maintain MAP } \geq 65 \text { mmHg and serum lactate level }>2 \text { mmol/L }\end{array}$ \\
\hline
\end{tabular}

\section{Management of confirmed Cases of COVID 19}

\section{Mild Cases}

A. Asymptomatic \& NO abnormal lab findings or HRCT findings of COVID 19 pneumonia:

(e.g. contact to confirmed case of COVID-19)

- Baseline investigations

- Laboratory work-up: CBC, CRP, D-dimer, Ferritin, Liver function tests (ALT - AST) and kidney function tests (S.cr- BUN).

- $\quad$ HRCT chest (to rule out Covid-19 pneumonia)

\section{- Management}

- No symptoms ---- $\rightarrow$ Isolation, rest, good nutrition, good oral hydration \& follow up the patient 
progress.

Site of Care: Home isolation

B. Asymptomatic \& abnormal lab findings or HRCT findings of COVID 19 pneumonia:

- If there are abnormal lab findings or HRCT findings of COVID 19 pneumonia $----\rightarrow$ treat as moderate illness

- Baseline investigations

- Laboratory work-up: CBC, CRP, D-dimer, Ferritin, Liver function tests (ALT - AST) and kidney function tests (S.cr-BUN).

- $\quad$ HRCT chest (to rule out Covid-19 pneumonia)

- Management

- Isolation, rest, good nutrition, good oral hydration \& follow up the patient progress.

- $\$$ Treat at home if D-dimer $<1 \mathrm{mg} / \mathrm{L}$, Absolute lymphopenia $<800 / \mu \mathrm{l}$, Ferritin $<500 \mathrm{ng} / \mathrm{ml}$., liver function within normal otherwise treat at Designated hospital

Site of Care: Designated hospital or Home isolation $\$$ if appropriate conditions are available/ Ain Shams University Student Dormitory (case by case assessment)

C. Symptomatic cases \& No HRCT findings of COVID 19 pneumonia without risk factors Patients with mild symptoms

- Baseline investigations

- Laboratory work-up: CBC, CRP, D-dimer, Ferritin, Liver function tests (ALT - AST) and kidney function tests (S.cr-BUN).

- HRCT chest (to rule out Covid-19 pneumonia)

- Management

- Isolation, rest, good nutrition, good oral hydration.

- Symptomatic treatment:

- Paracetamol $500 \mathrm{mg}$ PRN or up to $2 \mathrm{gm} /$ day for fever and myalgia -

- Motility regulator (e.g. Mosapride 2.5.mg $1 \times 3$ half an hour before meals) + Proton pump inhibitor (Omeperazole) $40 \mathrm{mg} 1 \times 1$ half an hour before breakfast) for GIT symptoms.

- Supplements:

- Vitamin C $1 \mathrm{gm} /$ day.

- Zinc $50 \mathrm{mg}$ per day.

- Azithromycin: $500 \mathrm{mg}$ per day for 5 days OR Doxycycline oral $200 \mathrm{mg}$ once followed by $100 \mathrm{mg}$ daily for 5 days

- Hydroxychloroquine $400 \mathrm{mg}$ PO BID for one day followed by $200 \mathrm{mg}$ BID for5-10 days OR Chloroquine phosphate PO 500 mg BID for 5-10days.

- Baseline ECG \& follow up whenever needed (Contraindicated when QTC > than $450 \mathrm{~ms}$ in males and $470 \mathrm{~ms}$ in females, Myasthenia gravis, Retinal damage, Epilepsy, G6PD deficiency, Chronic Heart, Kidney or Liver disease \& Arrythmias. Maximum duration 5 days in all types of disease categories in outside Designated hospital setting or where close cardiac ECG monitoring cannot be possible. (See table 5)

- Prophylactic anticoagulation: Enoxaparin $40 \mathrm{mg} / 24 \mathrm{hr}$ or Rivaroxapan $10 \mathrm{mg}$ once daily or Apixaban $2.5 \mathrm{mg}$ PO BID. At any disease severity; if D-dimer $\geq 1 \mathrm{mg} / \mathrm{L}$ consider therapeutic anticoagulation. 
- Repeat RT-PCR at the end of isolation period if not available continue isolation until completing 10 days from onset of symptoms + Symptoms free for the last 3 days without medication NB: Cough and anosmia may be the only persistent symptoms left

- If there is any symptomatic progression repeat investigation and reconsult for re-categorization

Site of care: Home isolation if appropriate conditions are available /Ain Shams University Student Dormitory

\section{D-Symptomatic cases \& No HRCT findings of COVID 19 pneumonia with risk factors}

\section{- Baseline investigations}

- Laboratory work-up: CBC, CRP, D-dimer, Ferritin, Liver function tests (ALT - AST) and kidney function tests (S.cr-BUN).

- HRCT chest (to rule out Covid-19 pneumonia)

\section{- Management}

- Isolation, rest, good nutrition, good oral hydration.

- Symptomatic treatment:

- Paracetamol $500 \mathrm{mg}$ PRN or up to $2 \mathrm{gm} /$ day for fever and myalgia -

- Motility regulator (e.g. Mosapride 2.5.mg 1x3 half an hour before meals) + Proton pump inhibitor (Omeperazole) $40 \mathrm{mg} 1 \times 1$ half an hour before breakfast) for GIT symptoms.

- Supplements:

- - Vitamin C $1 \mathrm{gm} /$ day.

- $\quad$ - Zinc $50 \mathrm{mg}$ per day.

- Azithromycin: $500 \mathrm{mg}$ per day for 5 days OR Doxycycline oral $200 \mathrm{mg}$ once followed by $100 \mathrm{mg}$ daily for 5 days

- Hydroxychloroquine $400 \mathrm{mg}$ PO BID for one day followed by $200 \mathrm{mg}$ BID for5-10 days OR Chloroquine phosphate PO 500 mg BID for 5-10days.

- Baseline ECG \& follow up whenever needed (Contraindicated when QTC > than 450 ms in males and $470 \mathrm{~ms}$ in females, Myasthenia gravis, Retinal damage, Epilepsy, G6PD deficiency, Chronic Heart, Kidney or Liver disease \& Arrythmias. Maximum duration 5 days in all types of disease categories in outside Designated hospital setting or where close cardiac ECG monitoring cannot be possible. (See table 5)

- Prophylactic anticoagulation: Enoxaparin $40 \mathrm{mg} / 24 \mathrm{hr}$ or Rivaroxapan $10 \mathrm{mg}$ once daily or Apixaban $2.5 \mathrm{mg}$ PO BID. At any disease severity; if D-dimer $\geq 1 \mathrm{mg} / \mathrm{L}$ consider therapeutic anticoagulation.

- Available Antiviral drug: e.g. Lopinavir-Ritonavir (200/50mg) 2 tablets bid for 5-10 days or Favipiravir if available 1600mg twice day 1 then 600mg twice for 9 days

- Repeat RT-PCR at the end of isolation period for home or Ain Shams University Student Dormitory isolation Repeat RT-PCR at the end of isolation period if not available Continue isolation until completing 10 days from onset of symptoms + Symptoms free for the last 3 days without medication

NB: Cough and anosmia may be the only persistent symptoms left

If the patient is at designated hospital repeat RT-PCR after 5 days of treatment

$\circ$ ( if negative repeat after $24 \mathrm{hrs}$ if still negative; stop treatment and continue isolation for 10 days)

$\circ$ (if positive repeat every $48 \mathrm{hrs}$ and reconsult) 
- If there is any symptomatic progression repeat investigation and reconsult for re-categorization

Site of care: Home isolation if appropriate conditions are available / Ain Shams University Student Dormitory or Designated hospital (case by case assessment)

\section{Moderate Cases}

- Baseline investigations

- Laboratory work-up: CBC, CRP, D-dimer, Ferritin, Liver function tests (ALT - AST) and kidney function tests (S.cr-BUN).

- HRCT chest ( Covid-19 pneumonia)

- Pulse oximetry

- Baseline ECG ( QTc is considered prolonged if greater than $450 \mathrm{~ms}$ in males and $470 \mathrm{~ms}$ in females) $\&$ follow up whenever needed

\section{- Management}

- Isolation, rest, good nutrition, good oral hydration.

- Symptomatic treatment:

- Paracetamol $500 \mathrm{mg}$ PRN or up to $2 \mathrm{gm} /$ day for fever and myalgia -

- Motility regulator (e.g. Mosapride 2.5.mg $1 \times 3$ half an hour before meals) + Proton pump inhibitor (Omeperazole) 40 mg 1x1 half an hour before breakfast) for GIT symptoms.

- Supplements:

- Vitamin C $1 \mathrm{gm} /$ day.

- $\quad$ Zinc $50 \mathrm{mg}$ per day.

- Azithromycin: $500 \mathrm{mg}$ per day for 5 days

- Therapeutic anticoagulation: Enoxaparin $1 \mathrm{mg} / \mathrm{kg} / 12 \mathrm{hr}$ or Rivaroxapan $15 \mathrm{mg}$ BID or Apixaban 10 $\mathrm{mg}$ PO BID x 7days then $5 \mathrm{mg}$ BID At any disease severity; if D-dimer $\geq 1 \mathrm{mg} / \mathrm{L}$ consider therapeutic anticoagulation.

- Hydroxychloroquine $400 \mathrm{mg}$ PO BID for one day followed by $200 \mathrm{mg}$ BID for5-10 days OR Chloroquine phosphate PO 500 mg BID for 5-10days.

- Baseline ECG \& follow up whenever needed (Contraindicated when QTC > than 450 ms in males and $470 \mathrm{~ms}$ in females, Myasthenia gravis, Retinal damage, Epilepsy, G6PD deficiency, Chronic Heart, Kidney or Liver disease \& Arrythmias. Maximum duration 5 days in all types of disease categories in outside Designated hospital setting or where close cardiac ECG monitoring cannot be possible. . (See table 5)

- Available Antiviral drug: e.g. Lopinavir-Ritonavir (200/50mg) 2 tablets bid for 5-10 days or Favipiravir if available 1600mg twice day 1 then 600mg twice for 9 days.

- $\quad \pm$ Third generation cephalosporin (Ceftrioxone $1 \mathrm{gm} / 12 \mathrm{hrs} \mathrm{IV)}$

- Repeat RT-PCR after 5 days of treatment 
$\circ$ ( if negative repeat after $24 \mathrm{hrs}$ if still negative; stop treatment and continue isolation for 10 days)

- (if positive repeat every $48 \mathrm{hrs}$ and reconsult)

- If there is any symptomatic progression repeat investigation and reconsult for re-categorization

Site of care: Designated hospital

\section{Severe Cases}

- Baseline investigations

- Laboratory work-up: CBC, CRP, D-dimer, Ferritin, Liver function tests (ALT - AST) and kidney function tests (S.cr-BUN) or procalcitonin.

- HRCT chest ( Covid-19 pneumonia)

- Arterial blood gases analysis and follow up oxygen saturation by Pulse oximetry

- Baseline ECG ( QTc is considered prolonged if greater than $450 \mathrm{~ms}$ in males and $470 \mathrm{~ms}$ in females) follow up whenever needed

\section{- Management}

- Isolation, rest, good nutrition, good oral hydration.

- Symptomatic treatment:

- Paracetamol $500 \mathrm{mg}$ PRN or up to $2 \mathrm{gm} /$ day for fever and myalgia -

- Motility regulator (e.g. Mosapride 2.5.mg 1x3 half an hour before meals) + Proton pump inhibitor (Omeperazole) $40 \mathrm{mg} 1 \times 1$ half an hour before breakfast) for GIT symptoms.

- Supplements:

- Vitamin C $1 \mathrm{gm} /$ day.

- Zinc $50 \mathrm{mg}$ per day.

- Oxygen therapy: using nasal cannula or venturi mask aiming to keep the $\mathrm{SpO} 2 \geq 94 \%$

- Azithromycin: $500 \mathrm{mg}$ per day for 5 days

- Therapeutic anticoagulation: Enoxaparin $1 \mathrm{mg} / \mathrm{kg} / 12 \mathrm{hr}$. At any disease severity; if D-dimer $\geq 1$ $\mathrm{mg} / \mathrm{L}$ consider therapeutic anticoagulation.

- Hydroxychloroquine $400 \mathrm{mg}$ PO BID for one day followed by $200 \mathrm{mg}$ BID for5-10 days OR Chloroquine phosphate PO 500 mg BID for 5-10days.

- Baseline ECG \& follow up whenever needed (Contraindicated when QTC > than 450 ms in males and $470 \mathrm{~ms}$ in females, Myasthenia gravis, Retinal damage, Epilepsy, G6PD deficiency, Chronic Heart, Kidney or Liver disease \& Arrythmias. Maximum duration 5 days in all types of disease categories in outside Designated hospital setting or where close cardiac ECG monitoring cannot be possible. (See table 5)

- Available Antiviral drug: e.g. Lopinavir-Ritonavir (200/50mg) 2 tablets bid for 5-10 days or Favipiravir if available $1600 \mathrm{mg}$ twice day 1 then 600mg twice for 9 days.

- Third generation cephalosporin (Ceftrioxone $1 \mathrm{gm} / 12 \mathrm{hrs} \mathrm{IV)}$

- In case of cytokine storm consider adding Tocilizumab (Anti-IL6): 4-8 mg $/ \mathrm{kg}$. Dilute in $100 \mathrm{ml}$ of $0.9 \%$ saline and infused over 60 minutes - First dose is calculated as $8 \mathrm{mg} / \mathrm{kg}$ and the response is assessed, if the patient needs the second dose it should be calculated as $4 \mathrm{mg} / \mathrm{kg}$ after $12 \mathrm{hrs}$ (refer to the indications in notes page 26). 
- If Tocilizumab is not available we may give methylpredisonolone $1 \mathrm{mg} / \mathrm{kg} /$ day IV for 5 days; then $0.5 \mathrm{mg} / \mathrm{kg} /$ day IV for 2 days

- Prone positioning should be encouraged (unless contraindicated) (30 min / 2 hours) or as tolerated

- Repeat RT-PCR after 5 days of treatment

$\circ$ (if negative repeat after $24 \mathrm{hrs}$ if still negative; stop treatment and continue isolation for 10 days)

- (if positive repeat every $48 \mathrm{hrs}$ and reconsult)

- If there is any symptomatic progression repeat investigation and reconsult for re-categorization Site of care: Intermediate care unit.

\section{Critical Cases}

\section{Criteria for ICU admission}

1. Severe Cases: Patients who meet any of the following criteria:

- Respiratory rate; 30 breaths/min;

- Oxygen saturations< $93 \%$ at a rest state;

- Arterial partial pressure of oxygen (PaO2)/ Fraction of inspired oxygen (FiO2)<300 mm Hg.

- Patients with more than $50 \%$ lesions progression within 24 to 48 hours in lung imaging should be treated as severe cases.

2. Critical Cases Patients who meet any of the following criteria:

- Occurrence of respiratory failure requiring mechanical ventilation;

- Presence of shock; other organ failure that requires monitoring and treatment in the ICU.

\section{Definitions:}

- Acute respiratory distress syndrome (ARDS): (as per Berlin definition)

- Sepsis: (Sepsis III definition)

- Septic shock: Persisting hypotension despite volume resuscitation requiring vasopressors to maintain MAP $\geq 65 \mathrm{mmHg}$ and serum lactate level $>2 \mathrm{mmol} / \mathrm{L}$.

\section{Clinical Management of ICU Patients}

\section{Labs and Workup:}

CBC with differential, Urea/Electrolytes, Creatinine, CRP, LFTs, Ferritin, D-dimer, procalcitonin, Triglycerides, Troponin, creatine kinase, blood glucose, cultures, ECG, LDH and COVID-19 PCR tests every 72 hours.

\section{Imaging}

1. Chest x-ray, Chest HRCT or CTPA as needed.

2. Echocardiography.

3. Abdominal ultrasound if needed

Patients with Pneumonia (ICU admission): Concerning lab results will add G6PD screening if chloroquine will be used. 


\section{Antibiotics:}

- Meropenem $1 \mathrm{gm} q 8 \mathrm{~h}+$ Vancomycin $15-20 \mathrm{mg} / \mathrm{kg} /$ dose q 8 to 12 hours (or Linezolid $600 \mathrm{mg}$ IV q 12h) until culture results are available.

\section{Symptomatic treatment:}

- Paracetamol $500 \mathrm{mg}$ PRN or up to $2 \mathrm{gm} /$ day for fever and myalgia -

- Motility regulator (e.g. Mosapride 2.5.mg 1x3 half an hour before meals) + Proton pump inhibitor (Omeperazole) 40 mg 1x1 half an hour before breakfast) for GIT symptoms.

\section{Supplements:}

- Vitamin C $1 \mathrm{gm} /$ day.

- Zinc $50 \mathrm{mg}$ per day.

Therapeutic anticoagulation: Enoxaparin $1 \mathrm{mg} / \mathrm{kg} / 12 \mathrm{hr}$.

Hydroxychloroquine $400 \mathrm{mg}$ PO BID for one day followed by $200 \mathrm{mg}$ BID for5-10 days OR Chloroquine phosphate PO 500 mg BID for 5-10days.

Baseline ECG \& follow up whenever needed (Contraindicated when QTc > than $450 \mathrm{~ms}$ in males and $470 \mathrm{~ms}$ in females, Myasthenia gravis, Retinal damage, Epilepsy, G6PD deficiency, Chronic Heart, Kidney or Liver disease \& Arrythmias. Maximum duration 5 days in all types of disease categories in outside Designated hospital setting or where close cardiac ECG monitoring cannot be possible. (See table 5)

Available Antiviral drug: e.g. Lopinavir-Ritonavir (200/50mg) 2 tablets bid for 5-10 days or Favipiravir if available 1600mg twice day 1 then 600mg twice for 9 days.

In case of cytokine storm consider adding Tocilizumab (Anti-IL6): 4-8 mg $/ \mathrm{kg}$. Dilute in $100 \mathrm{ml}$ of $0.9 \%$ saline and infused over 60 minutes - First dose is calculated as $8 \mathrm{mg} / \mathrm{kg}$ and the response is assessed, if the patient needs the second dose it should be calculated as $4 \mathrm{mg} / \mathrm{kg}$ after $12 \mathrm{hrs}$ (refer to the indications in notes Page 26).

If Tocilizumab is not available we may give methylpredisonolone $1 \mathrm{mg} / \mathrm{kg} /$ day IV for 5 days; then $0.5 \mathrm{mg} / \mathrm{kg} /$ day IV for 2 days

Prone positioning should be encouraged (unless contraindicated) (30 min / 2 hours) or as tolerated

\section{Contraindications of Prone positioning:}

\section{Absolute contraindications:}

- Shock (eg, persistent mean aterial pressure $<65 \mathrm{mmHg}$ )

- Acute bleeding (eg, hemorrhagic shock, massive hemoptysis)

- Multiple fractures or trauma (eg, unstable fractures of femur, pelvis, face) 
- Spinal instability

- Pregnancy

- Raised intracranial pressure $>30 \mathrm{mmHg}$ or cerebral perfusion pressure $<60 \mathrm{mmHg}$

- Tracheal surgery or sternotomy within two weeks

Relative contraindications:

- Recent DVT treated for $<2$ days

- Anterior chest tube(s) with air leaks

- Major abdominal surgery

- Recent pacemaker

- Clinical conditions limiting life expectancy (eg, oxygen or ventilator-dependent respiratory failure)

\section{Fluid Management:}

- Fluid balance with fluid restriction policy to keep balance either net or slightly negative with consideration to hemodynamics and renal perfusion.

- Crystalloids, avoid dextrose and synthetic colloids. Use albumin only if level very low $(<2 \mathrm{~g} / \mathrm{dl})$.

\section{Management of oxygen therapy and monitoring:}

- Supplemental oxygen therapy should be started immediately to patients in the following condition with target SpO2 $\geq 94 \%$ : Emergency signs (obstructed or absent breathing, severe respiratory distress, central cyanosis, shock, coma, or convulsions).

- Airway management and oxygen therapy during resuscitation may be required.

- The staff should use appropriate devices and flow rates in order to achieve the target saturation range

- Prompt clinical assessment is required if oxygen therapy needs to be initiated or increased due to a falling saturation level.

- Initiate oxygen therapy by oxygen cannula, titrate flow rates to reach target $\mathrm{SpO} 2 \geq 94 \%$ during resuscitation; or use face mask, or face mask with reservoir bag (at 10-15 L/min) if patient in critical condition.

\section{Closely monitor patients with COVID-19 for signs of clinical deterioration, such as:}

- $\uparrow \mathrm{RR}>30$ /min - $\downarrow$ Spo2 less 90\% - HR more than 120/min - 个 oxygen therapy;

- Then check $A B G$, rapidly progressive respiratory failure ( $\downarrow$ po 2 less than $60 \mathrm{mmHg}$ or $\uparrow$ pco 2 more than $50 \mathrm{mmHg}$ with acidosis $\mathrm{pH}$ less than 7.25)

- $\quad$ And consider Chest imaging, Sepsis work up, and ECHO

In addition to escalation of oxygen supportive care with: HFNO or NIPPV

Don't initiate either HFNO or NIV in severe form of ARDS i.e. PaO2: FiO2 Less than 100 and go straight to invasive mechanical ventilation 
- Reassess after $1 / 2$ hour: If stabilized spo $2>92 \%$, no increase in work of breathing, and not using accessory muscle, keep on with vigilant continuous monitoring and reassess after $2 \mathrm{~h}, 6 \mathrm{~h}$, and 12 h.

- Wean oxygen q 2 hours if $\mathrm{SpO} 2$ is $95 \%$ or more (consider lower levels in case of chronic respiratory failure)

\section{High-flow nasal oxygen (HFNO)}

- Avoid flow of more than $30 \mathrm{~L} / \mathrm{min}$ to minimize aerosolization.

- After initiation of high flow, evaluate at 2 hours, if patient improved and meeting safe ventilation criteria by ROX score ((Spo2/FiO2)/RR $\geq 4.88$ at 2, 6 and $12 \mathrm{hrs}$.) no need for intubation but if less than 3.85 is high risk then consider need for invasive ventilation.

\section{Non-Invasive ventilation (NIV)}

- Risks include delayed intubation, large tidal volumes, and injurious transpulmonary pressures.

- Shift to invasive ventilation if tidal volume more than $9 \mathrm{ml} / \mathrm{kg}$ of predicted body weight

\section{Indications of invasive mechanical ventilation:}

- Spo2 is not stabilized (P/F less than 150)

- Increased work of breathing

- Using accessory muscles

The following recommendations pertain to mechanically ventilated adult patients with ARDS:

- Implement mechanical ventilation using lower tidal volumes $(8 \mathrm{ml} / \mathrm{kg}$ predicted body weight, PBW) and decrease down to $4 \mathrm{ml} / \mathrm{kg}$ to maintain plateau pressure $<30 \mathrm{cmH} 2 \mathrm{O}$.

NB. Start nor-epinephrine infusion to prevent hypotension associated with intubation and mechanical ventilation initiation.

- Bronchoscopy should only be done if it will change clinical management

- Permissive hypercapnia is permitted.

- All patients with moderate to severe ARDS should receive a central venous catheter and an arterial line.

- The use of deep sedation is required to control respiratory drive and achieve tidal volume targets and avoid ventilator dyssynchrony.

- Conservative fluid management strategy for ARDS patients is preferred without tissue hypoperfusion.

- Identify high-risk patients with ARDS. ? age more than 60 years old ? Comorbid diseases such as diabetes, CKD, COPD, BA, and hypertension ? High APACHE II score ? Severe hypoxemia ( $\mathrm{PaO} 2: \mathrm{FiO} 2$ less than 100) ? Shock (hypotension with hypoperfusion) 
- Once intubated and on mechanical ventilation, some authors suggested that there are two Phenotypes of acute respiratory failure.

\section{Phenotypes of acute respiratory failure in COVID-19 patients:}

1. Phenotype "L" (atypical ARDS) characterized by Low elastance (high respiratory compliance),

2. Phenotype " $H$ " (ARDS like) characterized by High elastance (low compliance),

- Ventilator settings should be adjusted for each phenotype, low PEEP in type L, and recruitment maneuvers in type $\mathrm{H}$. Keeping driving pressure of 15 or less associated with improved outcome.

- In cases of moderate to severe ARDS and with presence of ventilation dyssynchrony despite adequate sedation, infusion of neuromuscular blockade agents, like atracurium should be started as early as possible. This may often be required for 48 to $72 \mathrm{hrs}$. Intermittent boluses can be given while waiting for infusion to start.

- If patient continues to deteriorate despite above treatment with P/F ratio below 150 , prone ventilation is recommended within 24-48 hours of ARDS onset. Proning should be maintained for 12-16 hours per day. Proning requires sufficient human resources and expertise to be performed safely.

- Once into prone position, an arterial blood gas should be done 30 minutes. If there is clear improvement, then patient should remain in prone position for at least 16-18 hours.

- If no clinical improvement in gas exchange or if there is further deterioration, patient should be maintained in supine position again

\section{Other aspects:}

- Use in-line catheters for airway suctioning and clamp endotracheal tube when disconnection is required (for example, transfer to a transport ventilator).

- Target Goal: PaO2 55-80 mmHg or SpO2 90-94\% or sometimes 88-92\%, pH 7.25-7.35

- Negative balance UOP $0.5 \mathrm{ml} / \mathrm{kg} / \mathrm{min}$ in case of AKI use CRRT. Plateau pressure $\leq 30 \mathrm{~cm} \mathrm{H} 2 \mathrm{O}$ NB: Avoid disconnecting the patient from the ventilator, which results in loss of PEEP and atelectasis.

\section{Extracorporeal membrane oxygenation (ECMO):}

\section{Indications for ECMO:}

- Severe Hypoxemia non responsive to proper mechanical ventilation: $\mathrm{PaO} 2: \mathrm{FiO} 2<50$ $\mathrm{mmHg}$ for $>3$ hours; or $\mathrm{PaO} 2$ : FiO2 $<80 \mathrm{mmHg}$ for $>6$ hours; regardless of the PEEP used. 
- Severe Hypercapnia non responsive to proper mechanical ventilation: $\mathrm{pH}<7.25$ with $\mathrm{PaCO} 280 \mathrm{mmHg}$ for $>6$ hours with a respiratory rate increased to 35 breaths per minute, adjusted for plateau pressure $32 \mathrm{cmH} 2 \mathrm{O}$.

- Proper mechanical ventilation should include lung protective ventilation (tidal volume 6 $\mathrm{ml} / \mathrm{kg}$, PEEP10-18 cm 20 ) was adopted and combined with lung recruitment maneuver, prone position ventilation, and nitric oxide if available. These patients who are still under the condition of pure oxygen inhalation, in these situations, ECMO should be considered for ARDS as rescue therapy when meeting one of the following criteria: (1) $\mathrm{PaO} 2 /$ FiO2<100 mmHg; (2) $\mathrm{P}(\mathrm{A}-\mathrm{a}) \mathrm{O} 2>600 \mathrm{mmHg}$; (3) $\mathrm{pH}<7.2$ and plateau pressure $>30 \mathrm{cmH} 2 \mathrm{O}$ with respiratory rate more than 35 breaths per minute; (4) Age<50 years old; (5) Mechanical ventilation $<7 d$; (6) Absence of contraindications.

\section{Contraindications for ECMO}

- Major pharmacologic immunosuppression (absolute neutrophil count $<400 / \mathrm{mm} 3$ )

- Evidence of bleeding or high risk of bleeding ie INR $>2.5$, platelet count $<50000$

- CNS hemorrhage that is recent or expanding

- Nonrecoverable comorbidity such as major CNS damage or terminal malignancy

- Chronic lung disease

- Acute neurological complication

- Age: above 50 years.

\section{Septic Shock}

- In the absence of a lactate measurement, use blood pressure (i.e. MAP) and clinical signs of perfusion to define shock.

- Standard care includes early recognition and the following treatments within 1 hour of recognition: antimicrobial therapy, and initiation of fluid bolus and vasopressors for hypotension.

- The use of central venous and arterial catheters should be based on resource availability and individual patient needs.

- In resuscitation for septic shock in adults, give $250-500 \mathrm{~mL}$ crystalloid fluid as rapid bolus in first 15-30 minutes and reassess for signs of fluid overload after each bolus.

- Fluid resuscitation may lead to volume overload, and respiratory failure.

- If there is no response to fluid loading or signs of volume overload appear (e.g. jugular venous distension, crackles on lung auscultation, pulmonary edema on imaging), then reduce or discontinue fluid administration.

- Crystalloids include normal saline and Ringer's lactate.

- Determine need for additional fluid boluses based on clinical response and improvement of perfusion targets. 
- Perfusion targets include MAP (> $65 \mathrm{mmHg}$ or previous known long standing blood pressureappropriate targets), urine output ( $>0.5 \mathrm{~mL} / \mathrm{kg} / \mathrm{hr}$ in adults), and improvement of skin mottling and extremity perfusion, capillary refill, heart rate, level of consciousness, and lactate.

- These indices include passive leg raises, fluid challenges with serial stroke volume measurements, or variations in systolic pressure, pulse pressure, inferior vena cava size, collapsibility, distensibility, or stroke volume response to changes in intrathoracic pressure during mechanical ventilation.

- In pregnant women, need to be placed in the lateral decubitus position to off-load the inferior vena cava.

- Norepinephrine is considered first-line treatment in adult patients; epinephrine can be added to achieve the MAP target. Because of the risk of tachyarrhythmia, reserve dopamine for selected patients with low risk of tachyarrhythmia or those with bradycardia.

- Consider dobutamine if maintained blood pressure with impaired tissue perfusion.

\section{Table 4: Prevention of complications in ICU}

\begin{tabular}{|c|c|}
\hline Anticipated outcome & Interventions \\
\hline $\begin{array}{l}\text { Reduce days of invasive } \\
\text { mechanical ventilation }\end{array}$ & $\begin{array}{l}\text { - Use weaning protocols that include daily assessment for } \\
\text { readiness to breathe spontaneously } \\
\text { - Minimize continuous or intermittent sedation, targeting specific } \\
\text { titration endpoints (light sedation unless contraindicated) or with } \\
\text { daily interruption of continuous sedative infusions }\end{array}$ \\
\hline $\begin{array}{l}\text { Reduce incidence of ventilator } \\
\text { associated pneumonia }\end{array}$ & $\begin{array}{l}\text { - Keep patient in semi-recumbent position (head of bed elevation } \\
30-45 \text {-) - Use a closed suctioning system; periodically drain and } \\
\text { discard condensate in tubing } \\
\text { - Use a new ventilator circuit for each patient; once patient is } \\
\text { ventilated, change circuit if it is soiled or damaged, but not } \\
\text { routinely } \\
\text { - Change heat moisture exchanger when it malfunctions, when } \\
\text { soiled, or every 5-7 days }\end{array}$ \\
\hline $\begin{array}{l}\text { Reduce incidence of catheter- } \\
\text { related bloodstream infection }\end{array}$ & $\begin{array}{l}\text { Use a checklist with completion verified by a real-time observer as } \\
\text { reminder of each step needed for sterile insertion and as a daily } \\
\text { reminder to remove catheter if no longer needed }\end{array}$ \\
\hline $\begin{array}{l}\text { Reduce incidence of pressure } \\
\text { ulcers }\end{array}$ & Turn patient every 2 hours \\
\hline $\begin{array}{l}\text { Reduce incidence of stress ulcers } \\
\text { and gastrointestinal (GI) } \\
\text { bleeding }\end{array}$ & $\begin{array}{l}\text { - Give early enteral nutrition (within } 24-48 \text { hours of } \\
\text { admission) } \\
\text { - Administer histamine-2 receptor blockers (famotidine) or } \\
\text { proton-pump inhibitors in patients with risk factors for GI } \\
\text { bleeding. Risk factors for GI bleeding include mechanical } \\
\text { ventilation for } \geq 48 \text { hours, coagulopathy, renal }\end{array}$ \\
\hline
\end{tabular}




\begin{tabular}{|l|l|}
\hline & \multicolumn{1}{|c|}{$\begin{array}{c}\text { replacement therapy, liver disease, multiple comorbidities, } \\
\text { and higher organ failure score }\end{array}$} \\
\hline $\begin{array}{l}\text { Reduce incidence of ICU-related } \\
\text { weakness }\end{array}$ & $\begin{array}{l}\text { Actively mobilize the patient early in the course of illness when } \\
\text { safe to do so }\end{array}$ \\
\hline
\end{tabular}

\section{Convalescent Plasma:}

If patient is not responding to other treatments, Convalescent plasma may be considered in setting of clinical trial. Only patients with confirmed COVID-19 should be considered for empirical convalescent plasma treatment, if they clinically deteriorate despite optimal antiviral therapy that required ICU care within 7 days of symptom onset. They must have severe or immediately life-threatening COVID-19 to be a candidate. Single dose of $200 \mathrm{ml}$ infusion with a titer of 1/320. Good responder: clearing of symptoms within 3 days, staring to clear lung fields after 7 days, and complete resolution within 10 days.

\section{Figure (1): Approach to acute desaturation:}

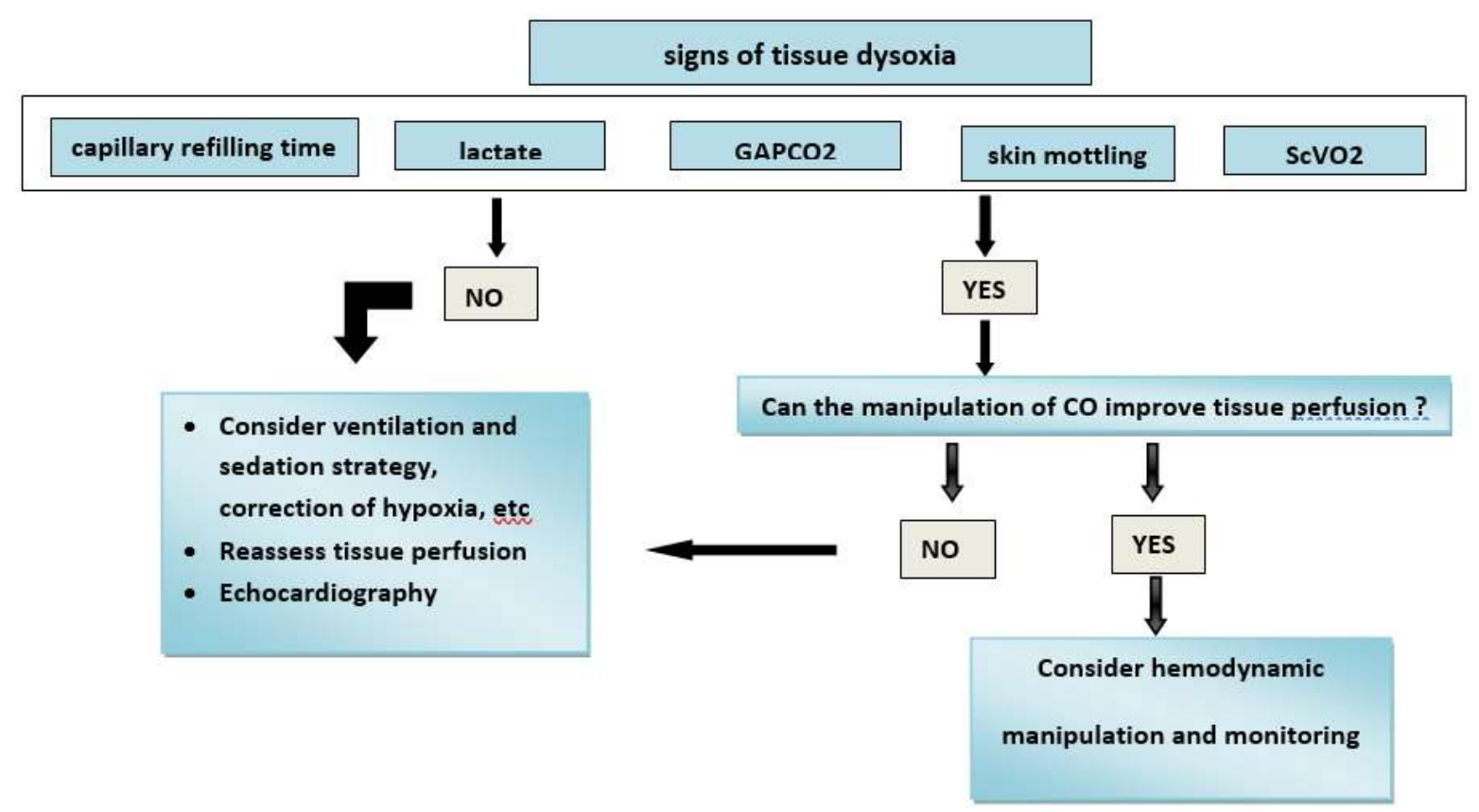

\section{Acute cor-pulmonale secondary to ARDS:}

\section{Precipitating factors:}

- P/F less than 150

- PaCO2 more than 46 mmhg

- Driving pressure more than $18 \mathrm{cmH} 2 \mathrm{O}$

\section{Treatment:}


- Decrease driving pressure less than $18 \mathrm{cmH} 2 \mathrm{O}$

- Decrease PEEP

- Increase respiratory rate

- Prone positioning

\section{Figure (2): Approach to new hypotensive event:}

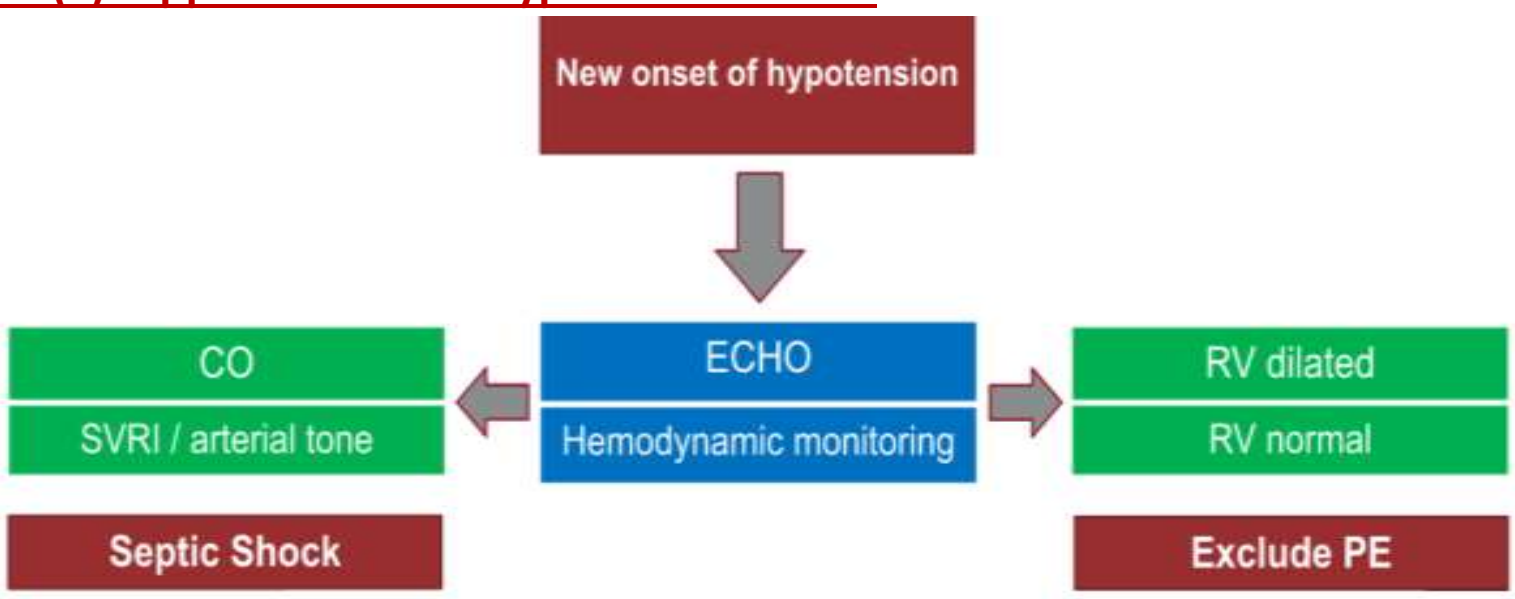

\section{TPA in refractory cardiorespiratory failure with unavailability of ECMO:}

\section{Indications:}

COVID-19-induced ARDS who have a P/F ratio 60 despite prone positioning and maximal mechanical ventilatory support.

Progressive pulmonary deterioration where there is no further mechanical ventilation capacity.

Dose: $25 \mathrm{mg}$ of tPA over 2 hours followed by a $25 \mathrm{mg}$ tPA infusion administered over the subsequent 22 hours, with a dose not to exceed $0.9 \mathrm{mg} / \mathrm{kg}$.

The same exclusion criteria currently in place for stroke will be used, with responders maintained for some period of time on a heparin infusion after completion of the tPA treatment.

\section{ICU discharge criteria}

1. Respiratory symptoms are significantly improved and stabilized;

2. There is no co morbidities or complications which require ICU care;

3. SpO2> 93\% with assisted oxygen inhalation equal or less than $4 \mathrm{~L} / \mathrm{min}$ by oxygen nasal cannula.

\section{Criteria of designated hospital Discharge}

- Body temperature remains normal for at least 3 days (ear temperature is lower than $37.5^{\circ} \mathrm{C}$ );

- Symptoms are significantly improved;

- Lung imaging shows improvement in lesions or even stationary; 
- There is no comorbidities or complications which require Designated hospitalization;

- Negative PCR is not necessary for discharge. Decision of patient discharge is based on the clinical assessment and evaluation.

- Discharged patients to be seen in the Designated hospital clinic after 2 weeks, unless patient develops respiratory symptoms to attend earlier.

- If asymptomatic at 2 weeks, no more follow up

- All patients after discharge should be isolated at home/ Ain Shams Dormitory until completing 10 days from onset of symptoms + Symptoms free for the last 3 days without medication and isolation instructions are to be given to the patients

- Treatment on discharge: Prophylactic anticoagulation: Rivaroxapan PO 10 mg once daily or Apixaban 2.5mg PO BID for 2 weeks.

\section{Important Notes:}

- Patients selection criteria for Tocilizumab: All of the following respiratory findings:

- Abnormal chest imaging consistent with COVID-19

- Rapidly worsening gas exchange/respiratory status over 24-48 hours and requiring $>4-6$ $\mathrm{L} / \mathrm{min} \mathrm{O} 2$

- Absence of systemic bacterial or fungal co-infection

- High clinical suspicion for cytokine release syndrome supported by elevated inflammatory markers (e.g., ferritin $>600 \mathrm{ug} / \mathrm{mL}$; D-dimer $>1 \mathrm{mg} / \mathrm{L}$ ) and clinical decline.

0 Does not have a poor prognosis where they are unlikely to survive $>48$ hours (in critical cases)

- Mechanical ventilation for $\leq 48$ hours (in Critical cases)

- Hydroxychloroquine is still present in the current treatment protocol because of its antiviral effect, due to limited availability of other antivirals.

- Table 5 : Risk Score For Drug-Associated QTc Prolongation (e.g. Hydroxychloroquine, azithromycin)

\begin{tabular}{|l|l|}
\hline Risk Factors Points & Points \\
\hline Age $\geq 68 \mathrm{y}$ & 1 \\
\hline Female sex & 1 \\
\hline Loop diuretic & 1 \\
\hline Serum K+ $\leq 3.5 \mathrm{mEq} / \mathrm{L}$ & 2 \\
\hline Admission QTc $\geq 450 \mathrm{~ms}$ & 2 \\
\hline Acute MI & 2 \\
\hline$\geq 2$ QTc-prolonging drugs & 3 \\
\hline sepsis & 3 \\
\hline Heart failure & 3 \\
\hline One QTc-prolonging drug & 3 \\
\hline Maximum Risk Score & 21 \\
\hline K+ indicates potassium; and Ml, myocardial infarction & \\
\hline
\end{tabular}

A Tisdale score of $\leq 6$ predicts low risk, 7-10 medium risk, and $\geq 11$ high risk of drug-associated QT prolongation Risk Levels For Drug-Associated QT Prolongation:

- $\quad$ Low risk $=\leq 6$ points

- $\quad$ Moderate risk $=7-10$ points

- $\quad$ High-risk $=\geq 11$ points 
- Probable cases by definition should be stratified and managed as the confirmed cases in time of pandemic

- If there is evidence of secondary bacterial infection (e.g. extensive lung lesions; excess bronchial secretions; chronic airway diseases; immunosuppressive medications) we may add antibiotics according to local antibiograms and cultures.

- Asymptomatic patient should be encouraged to practice home isolation.

- Contact: A contact is a person who experienced any one of the following exposures during the 2 days before and the 10 days after the onset of symptoms of a probable or confirmed case:

1. Face-to-face contact with a probable or confirmed case within 1 meter and for more than 15 minutes;

2. Direct physical contact with a probable or confirmed case;

3. Direct care for a patient with probable or confirmed COVID-19 disease without using proper personal protective equipment; OR

4. Other situations as indicated by local risk assessments.

- Patients with mild illness and patients with moderate uncomplicated disease with no comorbidities may be offered the opportunity for home isolation with proper instructions and regular follow up.

- If the patient has the appropriate conditions for home isolation, baseline investigations will be done and treatment will be decided accordingly.

- PCR will be done at the end of the 10 days period of home isolation; if not available continue isolation until completing 10 days from onset of symptoms + Symptoms free for the last 3 days without medication NB: Cough and anosmia may be the only persistent symptoms left 
Appendix 2

Home Isolation Guide 


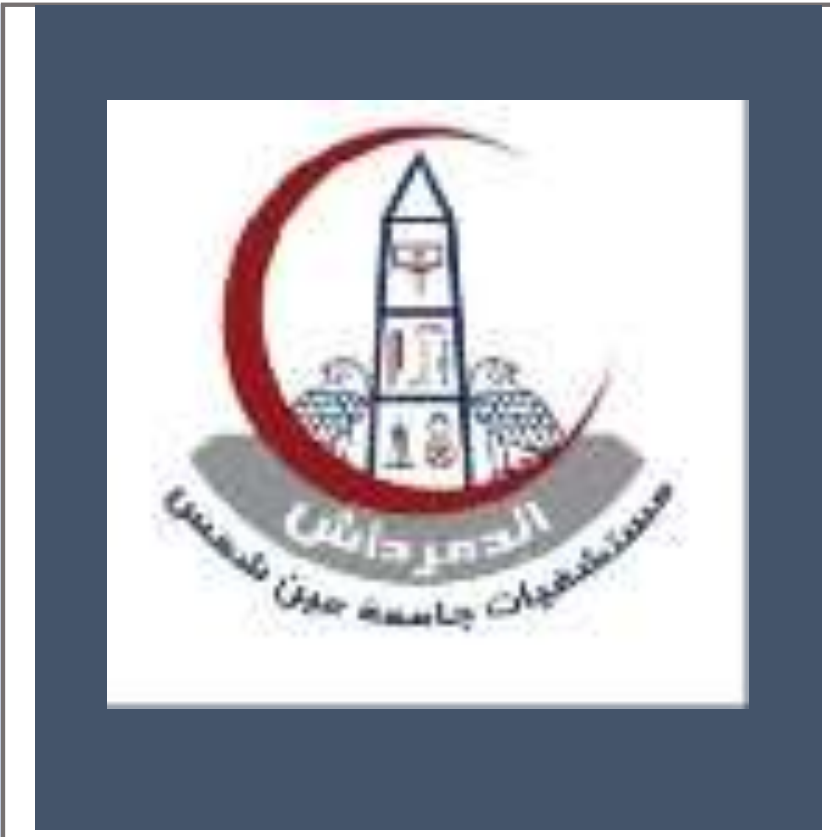

Ain Shams

University

Home isolation

booklet 


\section{Ain Shams University Home Isolation of Adult COVID-19 patients}

\section{Assess the suitability of home isolation if:}

- The patient is stable enough to receive care at home.

- Appropriate caregivers are available at home.

- There is a separate bedroom where the patient can recover without sharing immediate space with others.

- Resources for access to food and other necessities are available.

- The patient and other family members have access to appropriate, recommended personal protective equipment (at a minimum, gloves and facemask) and are capable of adhering to precautions recommended as part of home care or isolation (e.g., respiratory hygiene and cough etiquette, hand hygiene);

- There are household members who may be at increased risk of complications from COVID-19 infection (.e.g., older people and people with severe chronic health conditions, such as heart disease, lung disease, and diabetes).

Home isolation will be offered to: (Mild case severity)

1. Asymptomatic patients with NO abnormal laboratory findings and No HRCT findings of COVID 19 pneumonia

$\rightarrow$ Home isolation if appropriate conditions are available/ Ain Shams University Student Dormitory

2. Asymptomatic patients with abnormal laboratory findings or evidence of COVID 19 pneumonia in HRCT

(Treat ah home if D-dimer $<1 \mathrm{mg} / \mathrm{L}$, Absolute lymphopenia $>800 / \mu \mathrm{l}$, Ferritin $<500 \mathrm{ng} / \mathrm{ml}$., liver function within normal)

$\rightarrow$ Designated hospital or Home isolation if appropriate conditions are available/ Ain Shams University Student Dormitory (case by case assessment)

3. Symptomatic cases \& No HRCT findings of COVID 19 pneumonia without risk factors ( Patients with mild symptoms)

$\rightarrow$ Home isolation if appropriate conditions are available/ Ain Shams University Student Dormitory

4. Symptomatic cases \& No HRCT findings of COVID 19 pneumonia with risk factors $\rightarrow$ Home isolation if appropriate conditions are available / Ain Shams University Student Dormitory or Designated hospital (case by case assessment. 


\section{Baseline investigations:}

- Laboratory work-up:

$-\quad \mathrm{CBC}$

- $\quad$ CRP

- D-dimer

- $\quad$ Serum Ferritin

- $\quad$ Liver function tests (ALT - AST)

- $\quad$ kidney function tests (S.cr- BUN).

- $\quad$ ECG if the patient will receive Hydroxychloroquine

- $\quad$ Assess comorbidities as needed

- Patients in category 1: lab are not required to be repeated unless there is symptomatic progression

- Patients in category 2,3 and 4: only abnormal findings are required to be repeated after 5 days or if there is symptomatic progression.

- If $\mathrm{D}$-dimer $\geq 1 \mathrm{mg} / \mathrm{L}$ consider therapeutic anticoagulation

- HRCT chest (to rule out Covid-19 pneumonia)

- If there is any symptomatic progression repeat investigation and reconsult for re-assessment

\section{Management}

\section{Patients in category 1 and 2}

- Proper Isolation instructions

- Rest

- Good nutrition (fresh food- avoid processed food- limit intake of refined carbohydrates such as sugar, sweets, cake, soft drinks and sugar sweetened beverages - limit intake of foods containing trans-fats and saturated fats e.g. fat and skin from meat, hydrogenated vegetable oils, shortening, fried foods, cookies, and pastries).

- Good oral hydration (Fluid intake should be based on weight, on average $40 \mathrm{~kg}-60 \mathrm{~kg} \rightarrow$ $1.5-\mathrm{L} 2.0 \mathrm{~L}, 60-80 \mathrm{~kg} \rightarrow 2.0 \mathrm{~L}-2.5 \mathrm{~L}$, above $80 \mathrm{~kg} 2.5 \mathrm{~L}-3.0 \mathrm{~L}$ )

- Supplements:

- Vitamin C $1 \mathrm{gm} /$ day.

- Zinc $50 \mathrm{mg}$ per day.

- Follow up the patient Symptomatic progress

\section{Patients in category 3 and 4}

- Proper Isolation instructions

- Rest

- Good nutrition (fresh food- avoid processed food- Limit intake of refined carbohydrates such as sugar, sweets, cake, soft drinks and sugar sweetened beverages - Limit intake of foods containing trans-fats and saturated fats e.g. fat and skin from meat, hydrogenated vegetable oils, shortening, fried foods, cookies, and pastries). 
- Good oral hydration (Fluid intake should be based on weight, on average $40 \mathrm{~kg}-60 \mathrm{~kg} \rightarrow$ $1.5-\mathrm{L} 2.0 \mathrm{~L}, 60-80 \mathrm{~kg} \rightarrow 2.0 \mathrm{~L}-2.5 \mathrm{~L}$, above $80 \mathrm{~kg} 2.5 \mathrm{~L}-3.0 \mathrm{~L}$ )

- Supplements:

- Vitamin C $1 \mathrm{gm} /$ day.

- Zinc 50 mg per day.

- Symptomatic treatment:

1- Paracetamol $500 \mathrm{mg} P R N$ or up to $2 \mathrm{gm} /$ day for fever and myalgia -

2- Motility regulator (e.g. Mosapride 2.5.mg $1 \times 3$ half an hour before meals) + Proton pump inhibitor (Omeperazole) $40 \mathrm{mg} 1 \times 1$ half an hour before breakfast) for GIT symptoms.

- Azithromycin: $500 \mathrm{mg}$ per day for 5 days OR Doxycycline oral $200 \mathrm{mg}$ once followed by $100 \mathrm{mg}$ daily for 5 days

- Hydroxychloroquine $400 \mathrm{mg}$ PO BID for one day followed by $200 \mathrm{mg}$ BID for 5-10 days OR Chloroquine phosphate PO $500 \mathrm{mg}$ BID for 5-10 days.

- Prophylactic anticoagulation for two weeks:

- Rivaroxapan $10 \mathrm{mg}$ once daily or

- Apixaban 2.5mg PO BID.

- Follow up the patient Symptomatic progress

\section{Instructions for the caregiver and the patient:}

- Patients and household members should be educated about personal hygiene, basic IPC measures, and how to care as safely as possible for the person suspected of having COVID19 to prevent the infection from spreading to household contacts.

- The patient and household members should be provided with ongoing support and education, and monitoring should continue for the duration of home care.

- Household members should adhere to the following recommendations.

1- Place the patient in a well-ventilated single room (i.e. with open windows and an open door).

2- Limit the movement of the patient in the house and minimize shared space. Ensure that shared spaces (e.g. kitchen, bathroom) are well ventilated (keep windows open).

3- Household members should stay in a different room or, if that is not possible, maintain a distance of at least 1 meter from the ill person (e.g. sleep in a separate bed).

4- Limit the number of caregivers. Ideally, assign one person who is in good health and has no underlying chronic or immunocompromising conditions.

5- Visitors should not be allowed until the patient has completely recovered and has no signs or symptoms of COVID-19.

6- Perform hand hygiene after any type of contact with patients or their immediate environment.

7- Hand hygiene should also be performed before and after preparing food, before eating, after using the toilet, and whenever hands look dirty. If hands are not visibly 
dirty, an alcohol-based hand rub can be used. For visibly dirty hands, use soap and water.

8- When washing hands with soap and water, it is preferable to use disposable paper towels to dry hands. If these are not available, use clean cloth towels and replace them frequently.

9- To contain respiratory secretions, a medical mask should be provided to the patient and worn as much as possible, and changed daily. Individuals who cannot tolerate a medical mask should use rigorous respiratory hygiene; that is, the mouth and nose should be covered with a disposable paper tissue when coughing or sneezing. Materials used to cover the mouth and nose should be discarded or cleaned appropriately after use (e.g. wash handkerchiefs using regular soap or detergent and water).

10- Caregivers should wear a medical mask that covers their mouth and nose when in the same room as the patient. Masks should not be touched or handled during use. If the mask gets wet or dirty from secretions, it must be replaced immediately with a new clean, dry mask.

11- Remove the mask using the appropriate technique - that is, do not touch the front, but instead untie it. Discard the mask immediately after use and perform hand hygiene.

12- Avoid direct contact with body fluids, particularly oral or respiratory secretions, and stool. Use disposable gloves and a mask when providing oral or respiratory care and when handling stool, urine, and other waste. Perform hand hygiene before and after removing gloves and the mask.

13- Do not reuse masks or gloves.

14- Use dedicated linen and eating utensils for the patient; these items should be cleaned with soap and water after use and may be re-used instead of being discarded.

15- Daily clean and disinfect surfaces that are frequently touched in the room where the patient is being cared for, such as bedside tables, bedframes, and other bedroom furniture. Regular household soap or detergent should be used first for cleaning, and then, after rinsing, regular household disinfectant containing $0.1 \%$ sodium hypochlorite (i.e. equivalent to $1000 \mathrm{ppm}$ ) should be applied.

16-Clean and disinfect bathroom and toilet surfaces at least once daily. Regular household soap or detergent should be used first for cleaning, and then, after rinsing, regular household disinfectant containing $0.1 \%$ sodium hypochlorite should be applied.

17- Clean the patient's clothes, bed linen, and bath and hand towels using regular laundry soap and water or machine wash at $60-90{ }^{\circ} \mathrm{C}\left(140-194{ }^{\circ} \mathrm{F}\right)$ with common household detergent, and dry thoroughly. Place contaminated linen into a laundry bag. Do not shake soiled laundry and avoid contaminated materials coming into contact with skin and clothes.

18- Gloves and protective clothing (e.g. plastic aprons) should be used when cleaning surfaces or handling clothing or linen soiled with body fluids. Depending on the context, either utility or single-use gloves can be used. After use, utility gloves should 
be cleaned with soap and water and decontaminated with $0.1 \%$ sodium hypochlorite solution. Single-use gloves (e.g. nitrile or latex) should be discarded after each use. Perform hand hygiene before putting on and after removing gloves.

19- Gloves, masks, and other waste generated during home care should be placed into a waste bin with a lid in the patient's room before disposing of it as infectious waste. The disposal of infectious waste resides with the local sanitary authority.

20- Avoid other types of exposure to contaminated items from the patient's immediate environment (e.g. do not share toothbrushes, cigarettes, eating utensils, dishes, drinks, towels, washcloths, or bed linen).

21- When HCWs provide home care, they should perform a risk assessment to select the appropriate personal protective equipment and follow the recommendations for droplet and contact precautions.

When to discontinue home isolation:

- completing 10 days from onset of symptoms + Symptoms free for the last 3 days without medication.

NB: Cough and anosmia may be the only persistent symptoms left 


\section{Arabic resources}

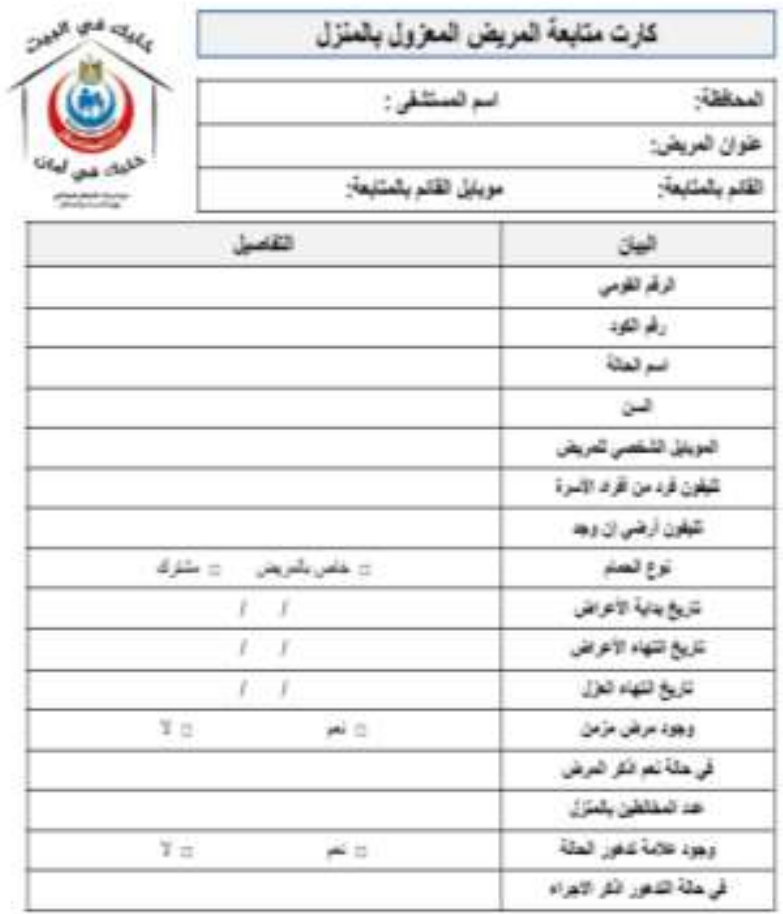

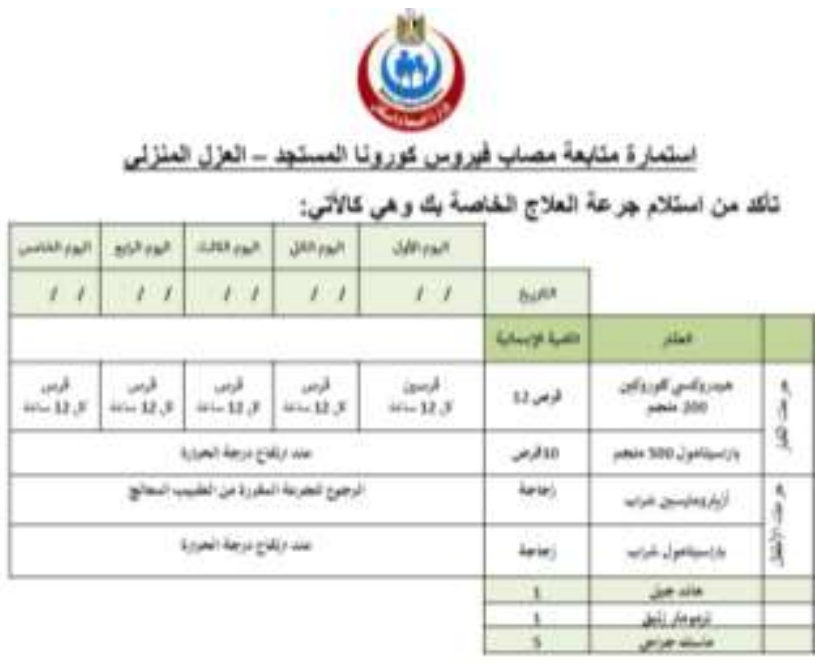

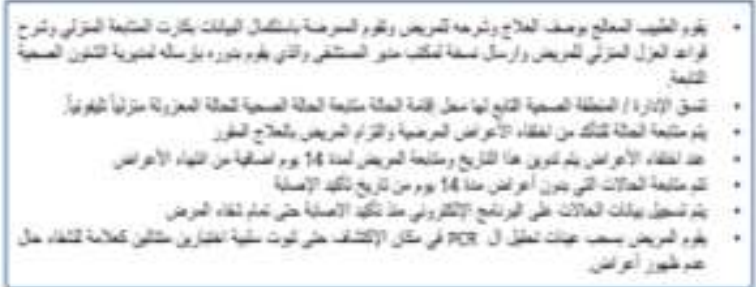

\begin{tabular}{|c|c|c|c|c|c|}
\hline & $y=$ & \multicolumn{2}{|c|}{$\sim \mathrm{a}$} & \multicolumn{2}{|c|}{ 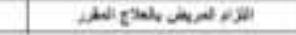 } \\
\hline & & \multirow{2}{*}{\multicolumn{2}{|c|}{ 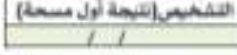 }} & & \\
\hline & & & & M & \\
\hline 2 & - & 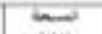 & & कion & \\
\hline zun & 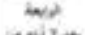 & 4) & 200 & 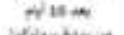 & 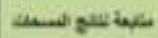 \\
\hline 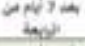 & - wisus & 40 & 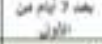 & 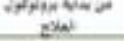 & \\
\hline 11 & 11 & 11 & 11 & 11 & 네피 \\
\hline
\end{tabular}



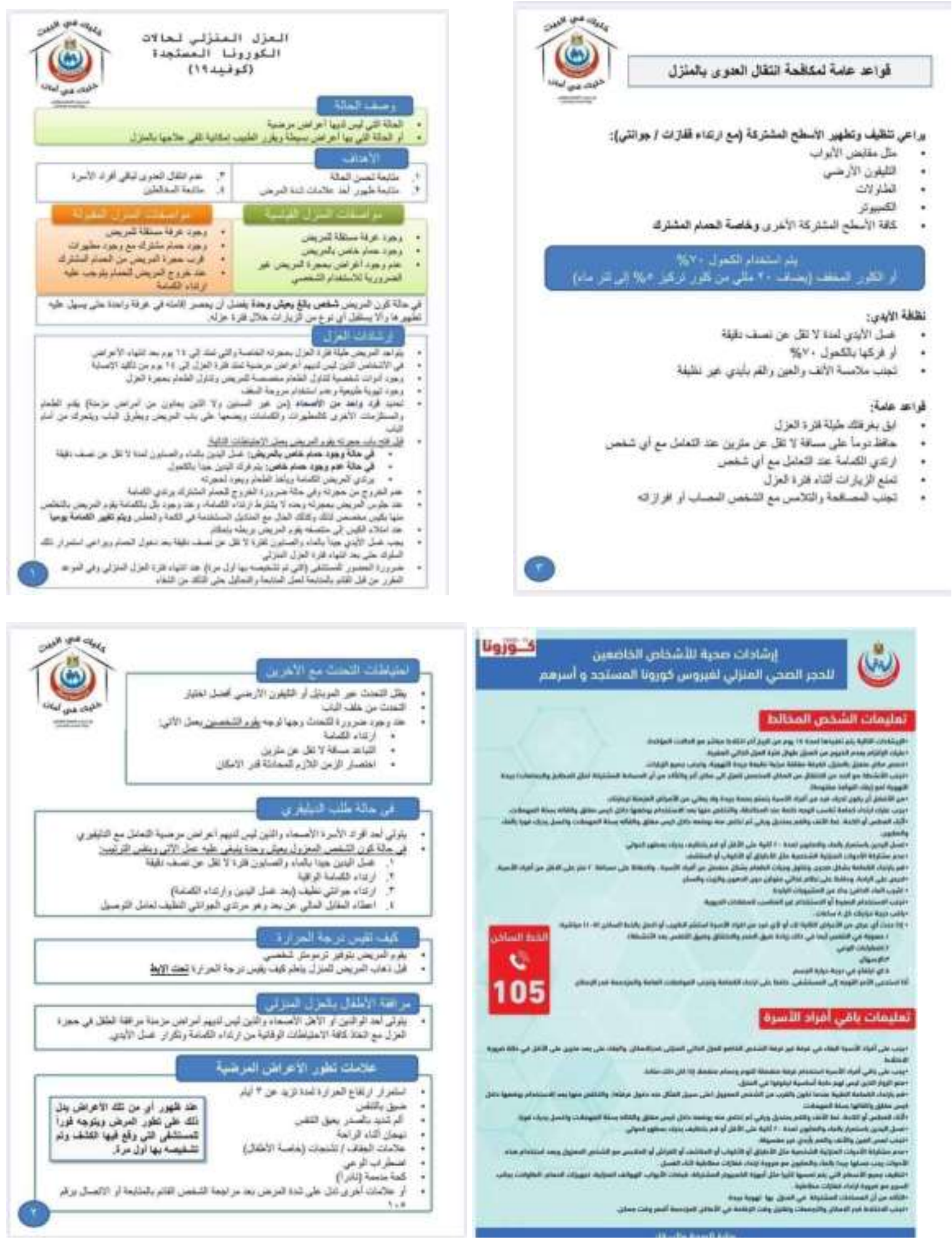

\section{$>\quad$ This is an updatable dynamic statement based on current available information and clinical experienc}





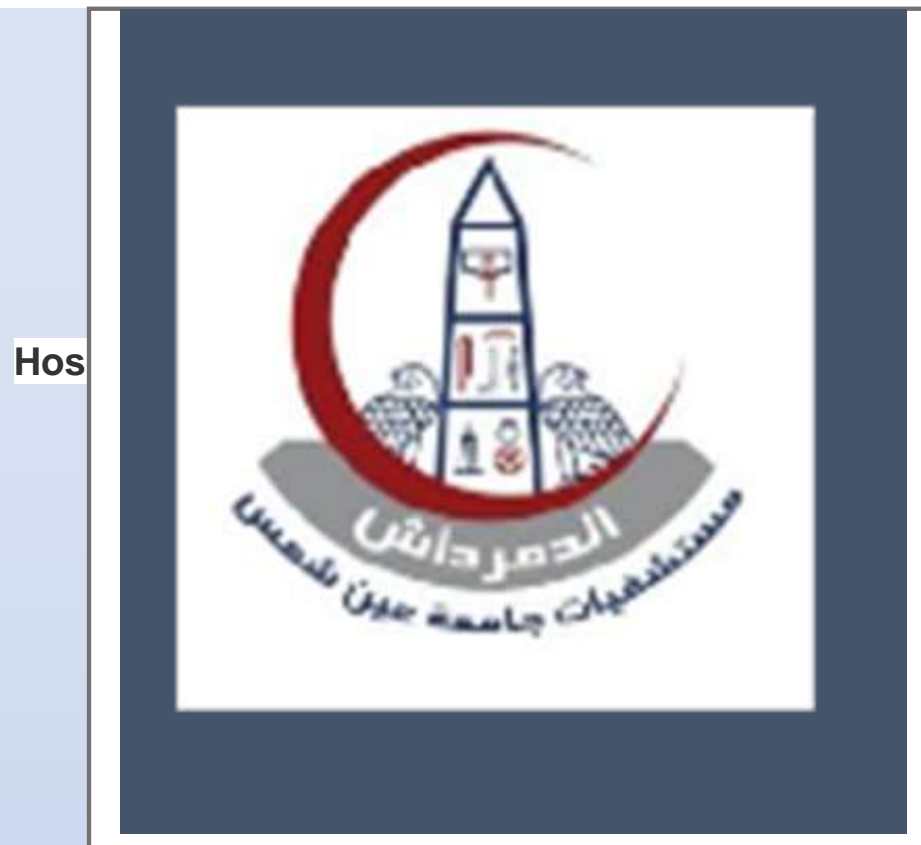

Ain Shams University Hospitals COVID-19 Pocket Guide 
Ain Shams University Hospitals COVID-19 Suspected Cases Algorithm

\section{Suspected case}

Health care workers \& Ain Shams University staff

\section{Triage Clinic for Evaluation $\$$}

Assess clinical /laboratory /HRCT/ Take PCR sample

\section{Suspected case}

In patient

Assess by Chest department Assess clinical/laboratory/HRCT/ Take PCR sample

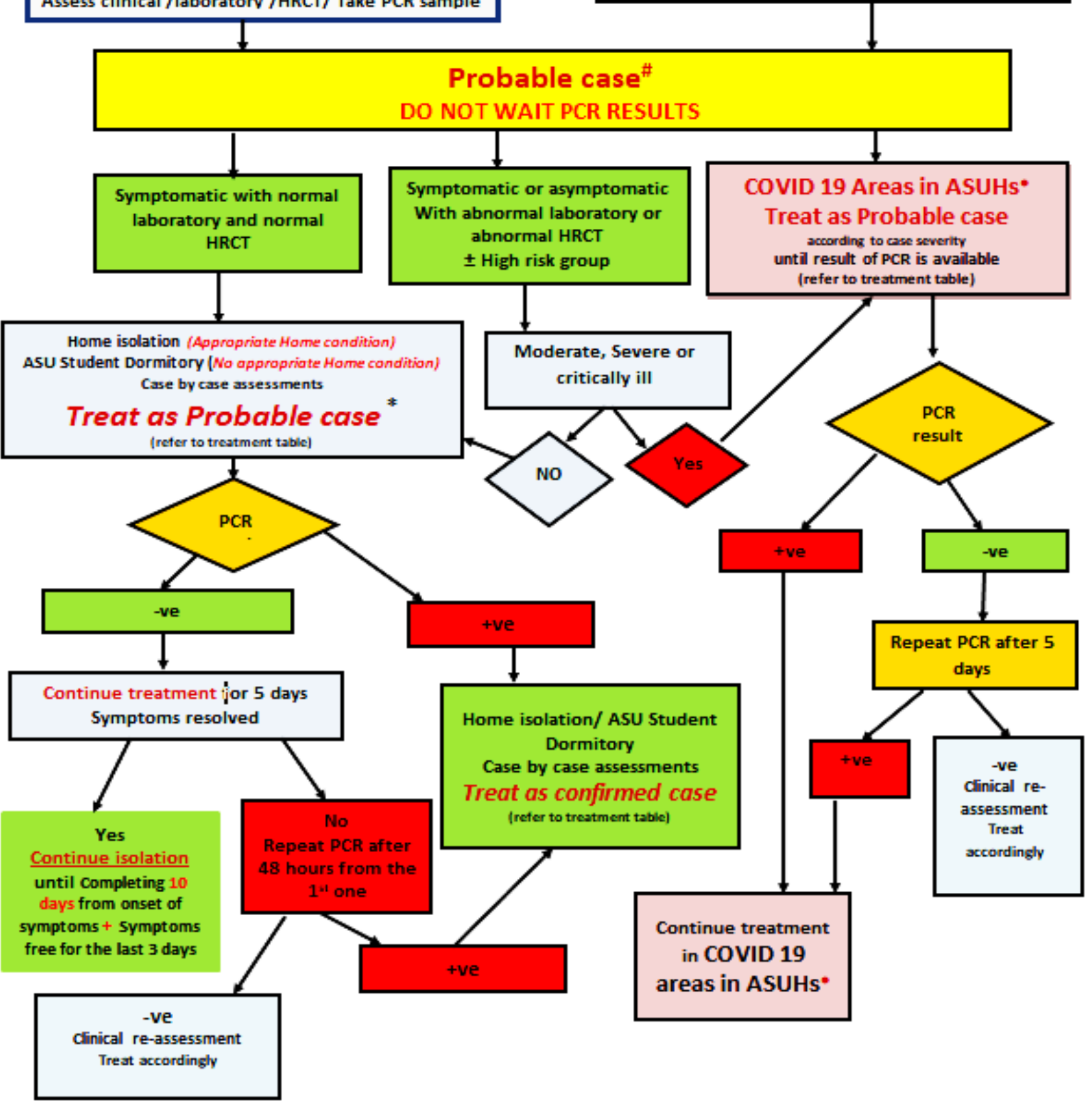

\$From 8 am to $8 \mathrm{pm}$ covered by Family Medicine / From 8 pm to 8 am covered by Internal Medicine in ER $\rightarrow$ Responsible to evaluate case and confirm the transfer of the case to site of care

IF THE PATIENT'S CONDITION DETERRIOATES at any time during treatment admit in COVID 19 area*

\# Clinical and radiological picture compatible with CVOID19 infection awaiting PCR result or repeatedly Negative PCR tests collected from different sites with no microbiological evidence of another Infectious etiology

-COVID 19 Areas in ASUHs: Obour hospital, Geriatric hospital, Field hospital and other areas (ER-ICU, old ER, Female Ophthalmology 


\section{Treatment Summary}

\section{Treatment of Confirmed Case of COVID-19}

\section{Mild Cases}

Asymptomatic

$\begin{array}{cccc}\text { Presentation } & \begin{array}{c}\text { NO abnormal } \\ \text { lab findings or } \\ \text { HRCT findings of } \\ \text { COVID 19 } \\ \text { pneumonia }\end{array} & \begin{array}{c}\text { Abnormal lab } \\ \text { findings or HRCT } \\ \text { findings of COVID } \\ 19 \text { pneumonia }\end{array} & \begin{array}{c}\text { No HRCT findings of } \\ \text { COVID } 19 \text { pneumonia } \\ \text { without risk factors }\end{array} \\ \text { Site of care } & \begin{array}{c}\text { Home } \\ \text { isolation/ } \\ \text { ASU Student } \\ \text { Dormitory }\end{array} & \begin{array}{c}\text { Designated } \\ \text { Hospital }\end{array} & \begin{array}{c}\text { Home isolation } \\ \text { or Home } \\ \text { isolation/ ASU } \\ \text { Student } \\ \end{array} \\ & \begin{array}{c}\text { Or ASU Student } \\ \text { Dormitory }\end{array} & \text { Dormitory }\end{array}$

Symptomatic

No HRCT findings of COVID 19 pneumonia with risk factors ${ }^{\circ}$ :

Home isolation/ ASU Student Dormitory or Designated hospital *

Treatment Isolation, rest, good nutrition, good oral hydration \& follow up patient response

Treat as
Moderate
illness

- Symptomatic treatment^

- Supplements\#

- $\quad$ Azithromycin: $\mathbf{5 0 0} \mathrm{mg}$ per day for $\mathbf{5 d a y s}$ OR Doxycycline oral $200 \mathrm{mg}$ once followed by $100 \mathrm{mg}$ daily for 5 days

- Anticoagulation :

Enoxaparin $40 \mathrm{mg} / 24 \mathrm{hr}$ or Rivaroxapan 10mg PO QD or Apixaban 2.5mg PO BID

- Hydroxychloroquine! $\mathbf{4 0 0} \mathrm{mg}$ PO BID for one day followed by $\mathbf{2 0 0} \mathrm{mg}$ BID for5-10 days OR Chloroquine phosphate! PO $500 \mathrm{mg}$ BID for 5-10days

- Available Antiviral drug ${ }^{\perp}$

\section{Moderate Cases}

Presentation Clinical signs of Non severe pneumonia (e.g. fever, cough, dyspnea) \& HRCT findings of COVID 19 pneumonia \& or Abnormal lab\$

Site of care:

Designated Hospital

Treatment

- Isolation, rest, good nutrition, good oral hydration \& follow up patient response

- Symptomatic treatment^

- Supplements\#

- Azithromycin: $\mathbf{5 0 0} \mathrm{mg}$ per day for $\mathbf{5 d a y s}$

- Anticoagulation :

- Enoxaparin $1 \mathrm{mg} / \mathrm{kg} / 12 \mathrm{hr}$ or Rivaroxapan $15 \mathrm{mg}$ BID or Apixaban $10 \mathrm{mg}$ PO BID x 7days then $5 \mathrm{mg}$ BID

- Hydroxychloroquine! $400 \mathrm{mg}$ PO BID for one day followed by $200 \mathrm{mg}$ BID for5-10 days OR Chloroquine phosphate! PO $500 \mathrm{mg}$ BID for 5-10days 
- Available Antiviral drug ${ }^{\perp}$

- $\quad \pm$ Third generation cephalosporin (Ceftriaxone $1 \mathrm{gm} / 12 \mathrm{hrs} \mathrm{IV)}$

\section{Severe Cases}

Presentation Clinical signs of Severe pneumonia (e.g. Respiratory rate $>30$ breaths/min; severe respiratory distress; or $\mathrm{SpO}_{2}$ $<93 \%$ on room air) \& HRCT findings of COVID 19 pneumonia

Site of care:

Designated Hospital/Intermediate care

Treatment

- Isolation, rest, good nutrition, good oral hydration \& follow up patient response

- Symptomatic treatment^

- Supplements\#

- Azithromycin: $\mathbf{5 0 0} \mathrm{mg}$ per day for $\mathbf{5 d a y s}$

- Anticoagulation :

○ Enoxaparin $1 \mathrm{mg} / \mathrm{kg} / 12 \mathrm{hr}$

- Hydroxychloroquine! $400 \mathrm{mg}$ PO BID for one day followed by $200 \mathrm{mg}$ BID for5-10 days OR Chloroquine phosphate! PO $500 \mathrm{mg}$ BID for 5-10days

- Available Antiviral drug ${ }^{\perp}$

- Prone positioning should be encouraged (unless contraindicated) (30 min / 2 hours) or as tolerated

- Third generation cephalosporin (Ceftrioxone $1 \mathrm{gm} / 12 \mathrm{hrs} \mathrm{IV)}$

- In case of cytokine storm consider adding Tocilizumab (Anti-IL6): 4-8 mg $/ \mathrm{kg}$. Dilute in $100 \mathrm{ml}$ of 0.9 $\%$ saline and infused over 60 minutes - First dose is calculated as $8 \mathrm{mg} / \mathrm{kg}$ and the response is assessed, if the patient needs the second dose it should be calculated as $4 \mathrm{mg} / \mathrm{kg}$ after $12 \mathrm{hrs}$.

- If Tocilizumab is not available we may give methylpredisonolone ( $1 \mathrm{mg} / \mathrm{kg} /$ day IV for 5 days; then $0.5 \mathrm{mg} / \mathrm{kg} /$ day IV for 2 days).

- $\quad$ Oxygen therapy \& further ICU management

\section{Critical Cases}

\begin{tabular}{|c|c|}
\hline Presentation & $\begin{array}{l}\text { Occurrence of respiratory failure requiring mechanical ventilation; Presence of shock; Sepsis, other organ failure } \\
\text { that requires monitoring and treatment in the ICU }\end{array}$ \\
\hline Site of care: & Designated Hospital/ ICU \\
\hline Treatment & $\begin{array}{l}\text { - Isolation, rest, good nutrition, good oral hydration \& follow up patient response } \\
\text { - Symptomatic treatment^ } \\
\text { - Supplements\# } \\
\text { - Azithromycin: } 500 \mathrm{mg} \text { per day for } 5 \text { days } \\
\text { - Anticoagulation: Enoxaparin } 1 \mathrm{mg} / \mathrm{kg} / 12 \mathrm{hr} \\
\text { - Hydroxychloroquine! } 400 \mathrm{mg} \text { PO BID for one day followed by } 200 \mathrm{mg} \text { BID for5-10 days OR Chloroquine } \\
\text { - } \text { phosphate! PO } 500 \mathrm{mg} \text { BID for } 5-10 \text { days } \\
\text { - Prone positioning should be encouraged (unless contraindicated) }(30 \mathrm{~min} / 2 \text { hours) or as tolerated }\end{array}$ \\
\hline
\end{tabular}


- Meropenem 1gm q $8 \mathrm{~h}+$ Vancomycin $15-20 \mathrm{mg} / \mathrm{kg} /$ dose q 8 to 12 hours (or Linezolid $600 \mathrm{mg}$ IV q $12 \mathrm{~h}$ ) until culture results are available

- In case of cytokine storm consider adding Tocilizumab (Anti-IL6): 4-8 mg / kg. Dilute in $100 \mathrm{ml}$ of 0.9 $\%$ saline and infused over 60 minutes - First dose is calculated as $8 \mathrm{mg} / \mathrm{kg}$ and the response is assessed, if the patient needs the second dose it should be calculated as $4 \mathrm{mg} / \mathrm{kg}$ after $12 \mathrm{hrs}$.

- If Tocilizumab is not available we may give methylpredisonolone ( $1 \mathrm{mg} / \mathrm{kg} /$ day IV for 5 days; then $0.5 \mathrm{mg} / \mathrm{kg} /$ day IV for 2 days).

- Convalescent Plasma if available

- Oxygen therapy / Non-Invasive ventilation / High-flow nasal cannula / Invasive mechanical ventilation \& further ICU management

\section{Remarks:}

- ASU: Ain Shams University Student Dormitory

- *Case by case assessment

- $\$$ Treat at home if D-dimer $<1 \mathrm{mg} / \mathrm{L}$, Absolute lymphopenia $<800 / \mu \mathrm{l}$, Ferritin $<500 \mathrm{ng} / \mathrm{ml}$., liver function within normal otherwise treat at Designated hospital

- ': High-risk group:Age above 60 years old, Obesity (BMl>40), pregnancy, comorbidities e.g. cardiovascular disease, diabetes, hypertension, chronic kidney disease or chronic respiratory disease (Asthma, COPD)...etc, Immunosuppressive diseases or drugs or active Malignancy

- If D-dimer $\geq \mathbf{1 ~} \mathbf{m g} / \mathrm{L}$ consider therapeutic anticoagulation

- ! Baseline ECG \& follow up whenever needed (Contraindicated when QTC > than 450 ms in males and $470 \mathrm{~ms}$ in females, Myasthenia gravis, Retinal damage, Epilepsy, G6PD deficiency, Chronic Heart, Kidney or Liver disease \& Arrythmias. Maximum duration 5 days in all types of disease categories in outside hospital setting or where close cardiac ECG monitoring cannot be

\begin{tabular}{|l|l|}
\hline \multicolumn{2}{|c|}{ Treatment of Probable Case of COVID 19+ Symptoms } \\
\hline Presentation & $\begin{array}{l}\text { Clinical and radiological picture compatible with CVOID19 infection awaiting PCR result or repeatedly } \\
\text { Negative PCR tests collected from different sites with no microbiological evidence of another Infectious } \\
\text { etiology }\end{array}$ \\
\hline Site of care: & Home isolation or hospital * \\
\hline Treatment & $\begin{array}{l}\text { Case managed as the confirmed cases in time of pandemic until PCR result is available } \\
\text { moderate, severe, or critical) }\end{array}$ \\
\end{tabular}

possible.

- $\quad \perp$ Antiviral drug: e.g. Lopinavir-Ritonavir (200/50mg) 2 tablets bid for 5-10 days. Oseltamivir is a neuraminidase inhibitor an enzyme not found on coronaviruses. Therefore, no activity is expected. 
- If patient's condition deteriorates, upgrade level of care, with immediate arrangement for transfer to hospital

- ^Symptomatic treatment

- Fever and myalgia: Paracetamol $500 \mathrm{mg}$ PRN or up to $2 \mathrm{gm} /$ day-

- GIT symptoms: Motility regulator (e.g. Mosapride 2.5.mg $1 \times 3$ half an hour before meals) + PPI (Omeperazole $40 \mathrm{mg} 1 \times 1$ half an hour before breakfast).

- \#Supplements:

- Vitamin C $1 \mathrm{gm} /$ day.

- Zinc 50 mg per day.

Table1: RT-PCR timeline:

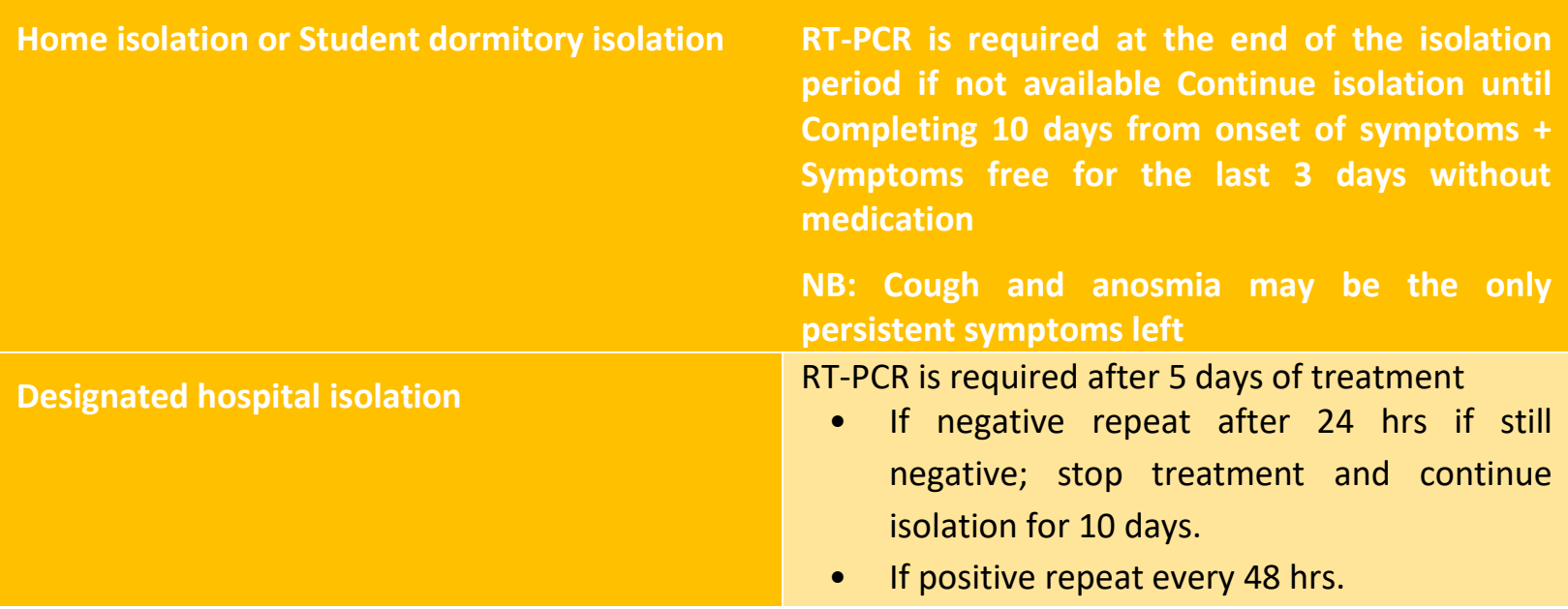

Table 2: Investigations schedule:

\begin{tabular}{|c|c|c|c|}
\hline Severity & Laboratory & Radiology & ECG \\
\hline Mild cases & $\begin{array}{l}\mathrm{CBC}, \mathrm{CRP} \text {, D-dimer, Ferritin, Liver } \\
\text { function tests (ALT - AST) and } \\
\text { kidney function tests (S.cr- BUN). } \\
\text { Base line, not required to be } \\
\text { repeated unless there is } \\
\text { symptomatic progression } \\
\text { In case of comorbidity: follow up } \\
\text { necessary lab as needed }\end{array}$ & $\begin{array}{l}\text { HRCT of the chest } \\
\text { Only repeat if } \\
\text { there } \\
\text { symptomatic } \\
\text { progression }\end{array}$ & $\begin{array}{l}\text { Baseline ECG ( QTc is } \\
\text { considered prolonged if } \\
\text { greater than } 450 \mathrm{~ms} \text { in } \\
\text { males and } 470 \mathrm{~ms} \text { in } \\
\text { females). } \\
\text { Only if the patient will } \\
\text { receive azithromycin } \\
\text { and/or } \\
\text { hydroxychloroquine }\end{array}$ \\
\hline $\begin{array}{l}\text { Moderate } \\
\text { cases }\end{array}$ & $\begin{array}{l}\text { - CBC, CRP, D-dimer, Ferritin, } \\
\text { Liver function tests (ALT - AST) } \\
\text { and kidney function tests (S.cr- } \\
\text { BUN). } \\
-\quad \text { Base line. } \\
\text { - Only abnormal findings are } \\
\text { required to be repeated as } \\
\text { needed }\end{array}$ & $\begin{array}{l}\text { HRCT chest } \\
\text { Repeat if there is } \\
\text { symptomatic } \\
\text { progression and } \\
\text { after } 2 \text { weeks of } \\
\text { discharge }\end{array}$ & $\begin{array}{l}\text { Baseline ECG ( QTC is } \\
\text { considered prolonged if } \\
\text { greater than } 450 \mathrm{~ms} \text { in } \\
\text { males and } 470 \mathrm{~ms} \text { in } \\
\text { females). } \\
\begin{array}{l}\text { Repeat every other day in } \\
\text { patients receiving }\end{array}\end{array}$ \\
\hline
\end{tabular}




\begin{tabular}{|c|c|c|c|}
\hline & $\begin{array}{l}\text { In case of comorbidity: follow up } \\
\text { necessary lab as needed }\end{array}$ & & $\begin{array}{l}\text { azithromycin and/ or } \\
\text { hydroxychloroquine }\end{array}$ \\
\hline Severe cases & $\begin{array}{l}\text {-CBC, CRP, D-dimer, Ferritin, } \\
\text { Liver function tests (ALT - AST) } \\
\text { and kidney function tests (S.cr- } \\
\text { BUN). } \\
\text { - Base line. } \\
\text { - Only abnormal findings are } \\
\text { required to be repeated as } \\
\text { needed } \\
\text { In case of comorbidity: follow up } \\
\text { necessary lab as needed }\end{array}$ & $\begin{array}{l}\text { Repeat if there is } \\
\text { symptomatic } \\
\text { progression and } \\
\text { after } 2 \text { weeks of } \\
\text { discharge }\end{array}$ & $\begin{array}{l}\text { Baseline ECG ( QTC is } \\
\text { considered prolonged if } \\
\text { greater than } 450 \mathrm{~ms} \text { in } \\
\text { males and } 470 \mathrm{~ms} \text { in } \\
\text { females). } \\
\text { Repeat every other day in } \\
\text { patients receiving } \\
\text { azithromycin and } \\
\text { hydroxychloroquine }\end{array}$ \\
\hline Critical cases & $\begin{array}{l}\text { - CBC with differential, } \\
\text { Urea/Electrolytes, Creatinine, } \\
\text { CRP, LFTs, Ferritin, D-dimer, } \\
\text { procalcitonin, Triglycerides, } \\
\text { Troponin, creatine kinase, blood } \\
\text { glucose, cultures, ECG, LDH. } \\
\text { - Base line. } \\
\text { - Required lab are to be } \\
\text { repeated as needed } \\
\text { In case of comorbidity: follow up } \\
\text { necessary lab as needed }\end{array}$ & $\begin{array}{l}\text { Repeat if there is } \\
\text { symptomatic } \\
\text { progression and } \\
\text { after } 2 \text { weeks of } \\
\text { discharge }\end{array}$ & $\begin{array}{l}\text { Baseline ECG ( QTC is } \\
\text { considered prolonged if } \\
\text { greater than } 450 \mathrm{~ms} \text { in } \\
\text { males and } 470 \mathrm{~ms} \text { in } \\
\text { females). } \\
\text { ECG is to be repeated as } \\
\text { needed } \\
\text { ECHO as needed }\end{array}$ \\
\hline
\end{tabular}

This is an updatable dynamic statement based on current available information and clinical experience 